\title{
Modern analogues for Miocene to Pleistocene alkali basaltic phreatomagmatic fields in the Pannonian Basin: "soft-substrate" to "combined" aquifer controlled phreatomagmatism in intraplate volcanic fields
}

Károly Németh ${ }^{1 *}$, Shane J. Cronin ${ }^{1}$, Miguel J. Haller ${ }^{2}$, Marco Brenna ${ }^{1}$, Gábor Csillag ${ }^{3}$

1 Volcanic Risk Solutions CS-INR, Massey University, PO Box 11 222, Palmerston North, New Zealand,

2 Universidad Nacional de la Patagonia San Juan Bosco - Sede Puerto Madryn, Consejo Nacional de Investigaciones Científicas y Técnicas, Argentina,

3 Geological Institute of Hungary, Department of Geological Research, Stefánia út 14, Budapest H-1143, Hungary,

Received 29 April 2010; accepted 4 June 2010

Abstract: The Pannonian Basin (Central Europe) hosts numerous alkali basaltic volcanic fields in an area similar to $200000 \mathrm{~km}^{2}$. These volcanic fields were formed in an approximate time span of 8 million years producing smallvolume volcanoes typically considered to be monogenetic. Polycyclic monogenetic volcanic complexes are also common in each field however. The original morphology of volcanic landforms, especially phreatomagmatic volcanoes, is commonly modified. by erosion, commonly aided by tectonic uplift. The phreatomagmatic volcanoes eroded to the level of their sub-surface architecture expose crater to conduit filling as well as diatreme facies of pyroclastic rock assemblages. Uncertainties due to the strong erosion influenced by tectonic uplifts, fast and broad climatic changes, vegetation cover variations, and rapidly changing fluvio-lacustrine events in the past 8 million years in the Pannonian Basin have created a need to reconstruct and visualise the paleoenvironment into which the monogenetic volcanoes erupted. Here phreatomagmatic volcanic fields of the Miocene to Pleistocene western Hungarian alkali basaltic province have been selected and compared with modern phreatomagmatic fields. It has been concluded that the Auckland Volcanic Field (AVF) in New Zealand could be viewed as a prime modern analogue for the western Hungarian phreatomagmatic fields by sharing similarities in their pyroclastic successions textures such as pyroclast morphology, type, juvenile particle ratio to accidental lithics. Beside the AVF two other, morphologically more modified volcanic fields (Pali Aike, Argentina and Jeju, Korea) show similar features to the western Hungarian examples, highlighting issues such as preservation potential of pyroclastic successions of phreatomagmatic volcanoes.

Keywords: phreatomagmatic $\cdot$ volcanic glass $\cdot$ sideromelane $\cdot$ maar $\bullet$ tuff ring $\cdot$ scoria cone $\cdot$ monogenetic $\bullet$ volcanic field - porous media aquifer $\cdot$ fracture-controlled aquifer

(C) Versita Warsaw 


\section{Introduction}

Monogenetic volcanism in temperate or tropical climate commonly manifests itself in the formation of phreatomagmatism-dominated volcanic fields. Smallvolume magma batches rise through slowly subsiding regions, and therefore monogenetic volcanism commonly occurs in basin-like and/or low lying areas with abundant shallow surface water and thick basin filling sediments acting as porous-media aquifer $[1,2]$. Due to the abundance of surface water availability as well as the water saturation of the fine-grained siliciclastic deposits, phreatomagmatism is expected in such environments. Monogenetic phreatomagmatic volcanism results in the formation of tuff cones, tuff rings and maars $[3,4]$. Erosion eventually causes the removal of the "softer" basement rock and leaves exposed the root zone of the individual monogenetic volcanoes.

Maar volcanoes differ morphologically from the traditional cone-shape volcanoes, as they usually have broad and deep craters surrounded by thin layers of tephra that form a surface ring. The formation of maar volcanoes is widely accepted to involve the explosive interaction of rising hot magma and water and/or water-saturated sediments [3]. Nevertheless, there is much debate as to whether it is magmatic gas or water, which drives the explosive magma fragmentation leading to the collapse of the volcanic crater and the formation of a diatreme, a funnel-shaped zone below the crater filled with volcanic and non-volcanic rocks and commonly crosscut by solidified magma. The tephra ring successions in modern basaltic volcanoes overwhelmingly support their phreatomagmatic origin (i.e. magmawater interaction driven explosive eruptions).

The information that can be gleaned from examining the exposed diatreme and the preserved near-vent tephra ring pyroclastic successions can be used to reconstruct the original volcanic landform and eruptive environment through comparison of preserved pyroclastic architecture and rock textures. Diatremes potentially "store" the most valuable information on how the magma and water interacted, and how the resulting fragmented rocks are transported away from their fragmentation site to the deposition sites surrounding the craters $[3,5]$. In addition the diatreme architecture provides insights into the collapse mechanism that eventually forms the maar $[3,5]$. While the study of diatremes and/or crater-filling deposits of phreatomagmatic volcanoes provide good information on the eruptive mechanism that formed these volcanoes, they can only be used indirectly to reconstruct the original volcanic landforms, and eventually model the eruptive environment of a phreatomagmatic volcanic field. In many cases the reconstruction of the eruptive environment of an older and eroded volcanic field is important to visualise how the eruptive scenario influenced the sedimentation in a sedimentary basin into which the volcanoes erupted. This is a long-lasting issue and research question in the case of many phreatomagmatic volcanic fields in the Pannonian Basin in Central Europe (Figure 1 \& 2), where volcanic fields represent advanced erosional stages allowing the investigation of the deeper levels of a volcanic edifice. Especially in its western segment intensive research has been carried out to understand the eruptive mechanism of phreatomagmatic volcanoes [6]. A comparative study on phreatomagmatic volcanism can provide vital new information on the external and internal forces responsible for the variety and types of volcanic landforms in monogenetic volcanic fields. Especially in older fields the erosion can be advanced and have exposed deeper levels of the volcanoes hindering the understanding of the driving mechanisms responsible for the formation of specific volcanic landforms. On the other hand young volcanic fields cannot provide information on the architecture of the vent and conduit zones. Therefore comparative and integrated studies are essential to develop more unified models for the evolution of monogenetic volcanic fields. The main parameters facilitating the understanding of the relative role of external versus internal factors responsible for the formation of specific volcanic landforms can be listed in order of importance:

- The type of substrate,

- The type of volcanic landforms,

- The preserved type of lithofacies associations of a volcano and

- The climatic and syn-eruptive environmental parameters influencing the availability of surface and/or ground-water.

In order to develop an integrated model, we selected three volcanic fields that are considered to be good analogues for better visualisation of the volcanic processes that created the Western Pannonian Basin's (WPB) phreatomagmatic volcanic fields (Figure $1 \& 2$ ). The basis of the selection is the similarity of pyroclastic architectures, textures and basement rock types as well as some climatic and environmental similarities. The volcanic fields compared here are dominated by phreatomagmatic volcanoes such as tuff rings, maars and tuff cones. Among these volcanoes, the main focus will be on various types of maar volcanoes and tuff rings. We also selected the three potential analogues in a time-progressive way to demonstrate how step by step volcanic landform and basin setting changes could be traced over millions of years of evolution, erosion, and 


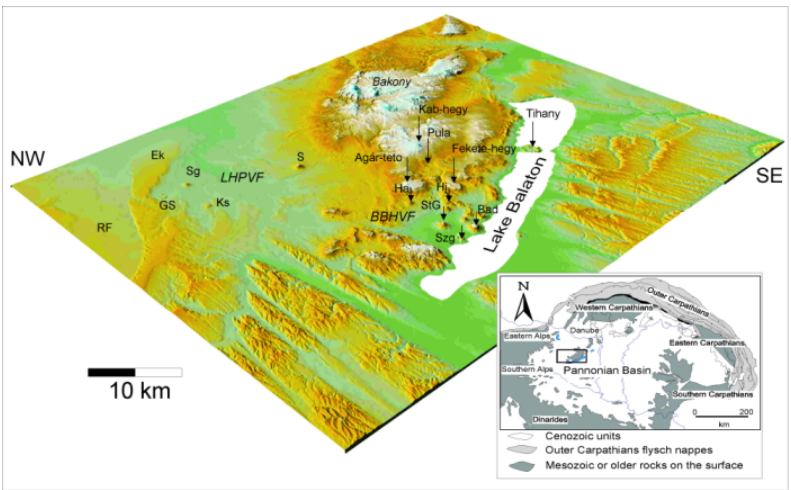

Figure 1. Oblique digital elevation model of the western Pannonian Basin shows erosion remnant of monogenetic volcanic fields. Note the strongly eroded morphology in the BBHVF in the centre of the area. Major volcanic remnants and landscape features are marked: RF Rába Fault Zone, GS - Gérce and Sitke tuff rings, Ks Kissomlyó tuff ring, Sg - Ság-hegy, Ek - Egyházaskesző, S - Somló-hegy, LHPVF - Little Hungarian Plain Volcanic Field, BBHVF - Bakony- Balaton Highland Volcanic Field, Ha - Haláp, StG - Szent György-hegy, Szg - Szigliget, Bad - Badacsony, $\mathrm{Hj}$ - Hajagos

subsequent sedimentation in regard to a phreatomagmatic volcanic field.

The active Auckland Volcanic Field (AVF) (Figure 3) has very young volcanoes ( $250 \mathrm{ka}$ to $0.6 \mathrm{ka}$ ), where erosion has not advanced enough to be able to exhume the diatremes $[7,8]$. Growing evidence suggests that Auckland is a typical phreatomagmatic volcanic field $[7,9,10]$. Intraplate basaltic volcanism in the Pannonian Basin (mostly in Hungary and surrounding countries) took place from Late Miocene till Pleistocene times in a strikingly similar environment to Auckland's volcanism [6]. The volcanic fields in the Pannonian Basin formed in an alluvial plain, flat land with abundant surface and ground-water sources. Because of this water-rich environment, large numbers of phreatomagmatic volcanoes formed in a typical "soft-substrate" controlled setting [6]. The volcanoes are, however, significantly older than Auckland, and intensive erosion exhumed many of the diatremes in these regions leaving them superbly exposed [11-13]. The volcanic fields of the WPB are particularly noteworthy and provide excellent outcrops where complete diatremes are exposed cutting through a typical soft-substrate country rock environment dominated by sand, gravel and silt.

In addition to the AVF, the Pali Aike, Argentina (PAVF) (Figure 4) and Jeju, Korea (JVF) (Figure 5) volcanic fields were selected for a brief comparison to demonstrate the potential erosional steps a phreatomagmatic volcanic field can go through culminating in a deeply eroded system such as the WPB. This comparative study
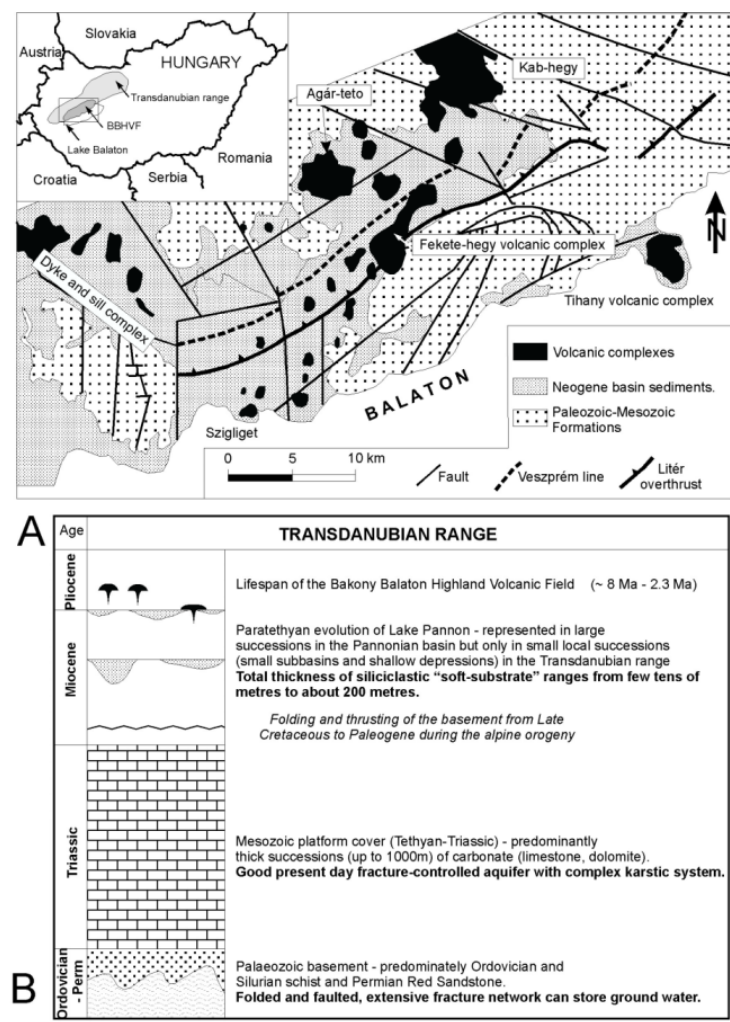

Figure 2. Simplified geological map of the BBHVF. Note the incomplete soft-substrate cover over hard country rocks. Major volcanic centres mentioned in the text are marked. Simplified stratigraphic column of the pre-volcanic rock units of the BBHVF showing characteristics of a mixed - soft and hard substrate environment, that is different from the soft-substrate dominated LHPVF pre-volcanic units.

provides also new insights into how maar-diatreme volcanism has evolved in the most common eruptive environment on Earth, where magma encounters thick piles of loose and water-saturated sediments (soft-substrate) and abundant surface water (e.g. alluvial plains, coastal plains).

Whereas the comparison among the selected volcanic fields is based on a sedimentological viewpoint, this work also highlights some peculiar behaviour of monogenetic volcanic fields, such as the evolutionary complexity their volcanoes may show. Monogenetic volcanic fields are traditionally viewed as clusters of vents in well-defined time and space settings, but their individual volcanoes can show gradual transition from sensu stricto small-volume monogenetic volcanoes through polycyclic-monogenetic and eventually polymagmatic (polycyclic) monogenetic volcanoes. The volcanic fields of the WPB and the three 


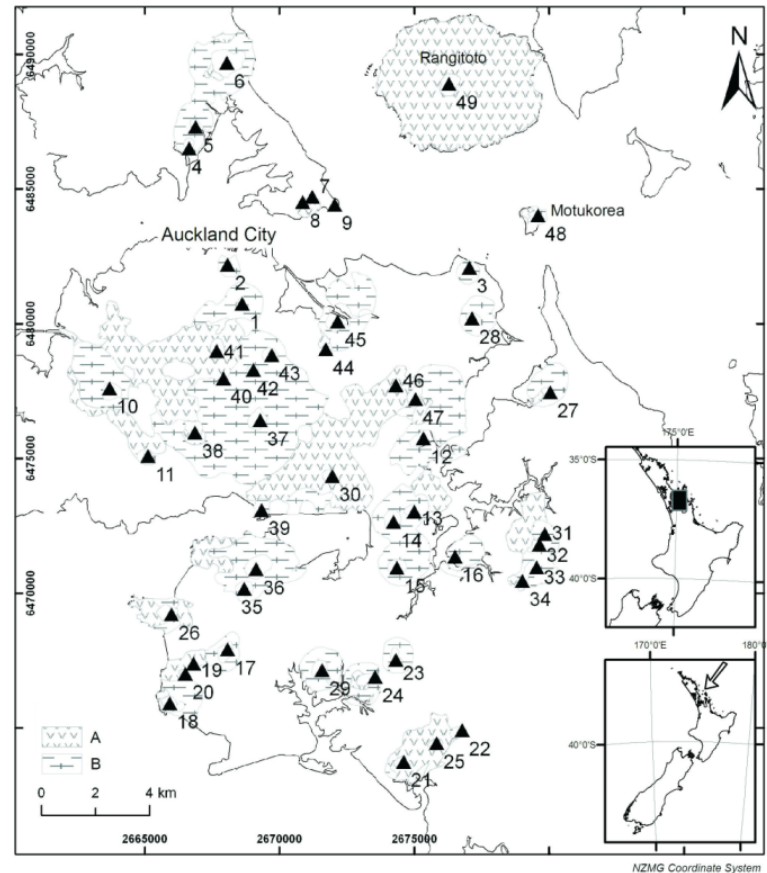

Figure 3. Map of the Auckland Volcanic Field showing the known volcanic centers (after Kermode, 1992). Numbers refer to individual eruptive centres: 1 - Auckland Domain, 2 - Albert Park, 3 - St Heliers, 4 - Onepoto, 5 - Tank Farm, 6 - Lake Pupuke, 7 - Mt Cambria, 8 - Mt Victoria, 9 - North Head, 10 - Mt Albert, 11 - Mt Roskill, 12 Panmure Basin, 13 - McLennan Hills, 14 - Mt Richmond, 15 - Robertson Hill,16 - Pukekiwiriki, 17 - Waitomokia, 18 - Maungataketake, 19 - Pukeiti, 20 - Otuataua, 21 - Matakarua, 22 - Ash Hill, 23 - Kohuora, 24 - Crater Hill, 25 - Wiri Mountain, 26 - Puketutu, 27 - Pigeon Mountain, 28 - Taylor Hill, 29 - Pukaki, 30 - Mt Smart, 31 - Styaks Swamp, 32 - Green Hill, 33 - Otara Hill, 34 Hampton Park, 35 - Mangere Lagoon, 36 - Mt Mangere, 37 - One Tree Hill, 38 - Three Kings, 39 - Hopua, 40 Te Pouhawaiki, 41 - Mt Eden, 42 - Mt St John, 43 - Mt Hobson, 44 - Little Rangitoto, 45 - Orakei Basin, 46 Purchas Hill, 47 - Mt Wellington, 48 - Motukorea, 49 Rangitoto

other volcanic fields used for comparison exhibit this spectrum, which implies a more global significance to our understanding of monogenetic volcanism.

\section{Volcanic Fields for Analogy}

We selected three volcanic fields representing phreatomagmatic explosive eruption-dominated volcanism over prolonged time as analogues to the oldest field developed in a Mio-Pliocene fluvio-lacustrine basin in Western Hungary. There, broad lensoid shape tuff

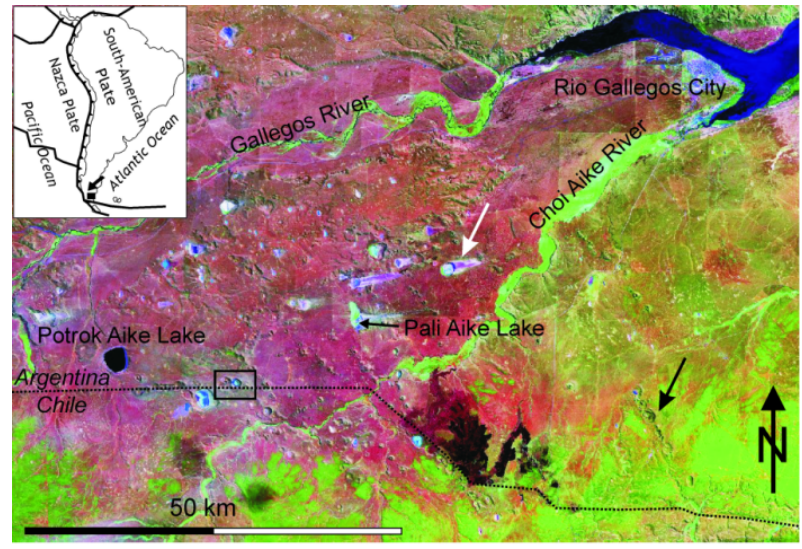

Figure 4. Satellite image shows the Pali Aike Volcanic Field. Note the aligned volcanic craters (e.g. black arrow) and the wind erosion marks (e.g. white arrow). In the rectangle a typical nested maar-scoria cone complex can be seen, a typical type of volcano from this field.

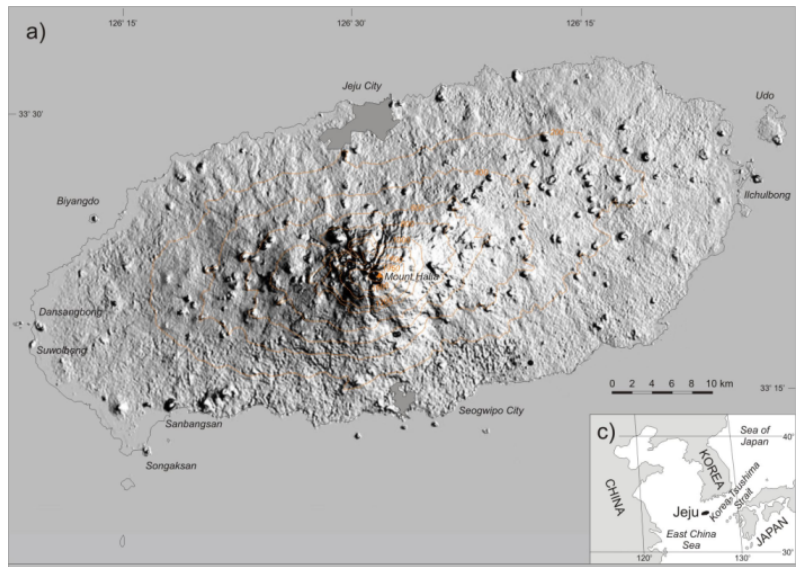

b)

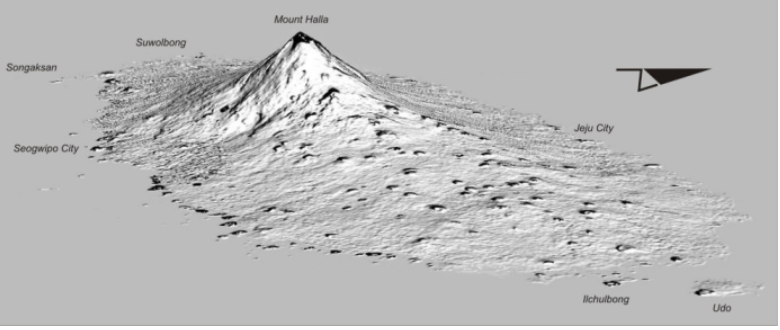

Figure 5. a) Digital elevation model and b) bird eye view looking east of Jeju Island with major volcanoes mentioned in the text marked. Note the apparently random distribution of small-volume volcanic cones around the major central volcano, Mount Halla. In b) the vertical exaggeration is x5. c) General location of Jeju Island.

rings and maars are preserved due to magmatic infill in their crater that prevented the erosion of the centre 
part of the volcanoes, leaving behind typical volcanic butte landforms (Figure 6A). The phreatomagmatic pyroclastic successions exhibit over 50 vol.\% accidental lithic fragments in their deposits $[6,14]$ (Figure 6B). Due to erosion, the preserved pyroclastic units cannot directly be correlated to penecontemporaneous siliciclastic successions, however, geomorphic evidence indicates that volcanism and fluvio-lacustrine deposition were synchronous. The majority of the preserved pyroclastic successions are inferred to represent proximal sites of former monogenetic volcanoes, many of them having the initial phreatomagmatic tuff ring part filled by scoria cones and associated lava lakes (Figure 6C).

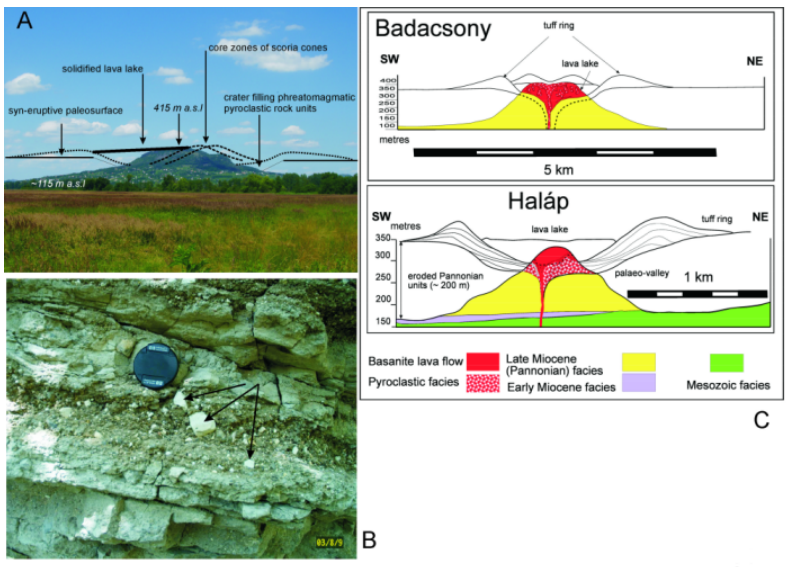

Figure 6. Typical magmatic eruptive product capped volcanic butte from the BBHVF with reconstructed volcanic facies architectures and associated volcanic landforms. Accidental lithic fragments from karst-water bearing hard substrate in a proximal phreatomagmatic deposit of the Pula maar in the BBHVF. The matrix of the rock is rich in siliciclastic fragments derived from the immediate underlying soft-substrate, suggesting mixed aquifer involvement in the phreatomagmatic explosive eruptions.

Reconstructed cross sections across two typical erosion remnants of the BBHVF.

Among the studied volcanic fields, the youngest ( $<250 \mathrm{ky})$, still active and therefore the best potential modern analogue for the WPB volcanic fields is the Auckland Volcanic Field, New Zealand (Figure 7A). Here, phreatomagmatic explosive eruptions took place almost in every volcano, at least in their initial phase, regardless of the location with respect to the sea level and/or the position of the vent with respect to the location of stream valleys [7]. The basal pyroclastic units of the thin $(<20 \mathrm{~m})$ rims commonly have over 90 vol.\% of accidental lithic fragments (Figure 8B). This highlights the role of the water-saturated siliciclastic country rock to fuel phreatomagmatism.

The Pali Aike Volcanic Field (PAVF) in Argentina provides a good analogy to demonstrate the preservation potential of pyroclastic successions in arid and windy climates
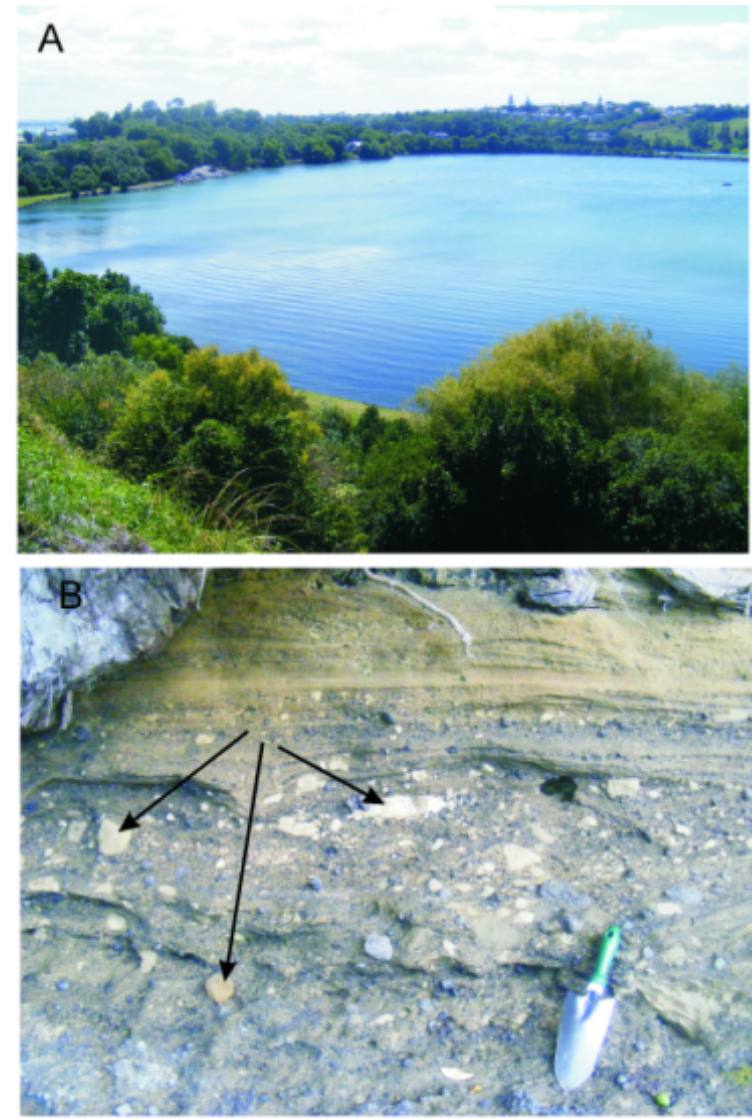

Figure 7. Broad and shallow maar surrounded by a thin crater rim deposit a typical volcano type (Orakei maar) from the Auckland Volcanic Field (AVF).

The basal phreatomagmatic successions of the majority of the AVF volcanoes consist of tuff breccias rich in plastically deformed and milled fragments from the immediate pre-volcanic siliclastic rock units, a typical watersaturated soft substrate.

(Figure 8A). Arid and windy conditions were reconstructed thorough the post-volcanic history of the WPB [15], in many respects a very similar scenario to the present day PAVF climatic conditions. The PAVF is older (4 Ma to Recent) than the AVF but the preserved volcanic landforms share similar geometrical parameters (Figure 8A) and pyroclastic deposit characteristics, such as abundant accidental lithics (Figure 8B). As a consequence a similar eruption mechanism with the western Hungarian Neogene alkali basaltic volcanic fields is inferred.

In Jeju, Korea (JVF), broad phreatomagmatic volcanoes $(<2 \mathrm{My})$ can be identified in the present day coastal plains $[16,17]$ (Figure 9A). In this respect Jeju provides a good comparison to the WPB due to their common low- 

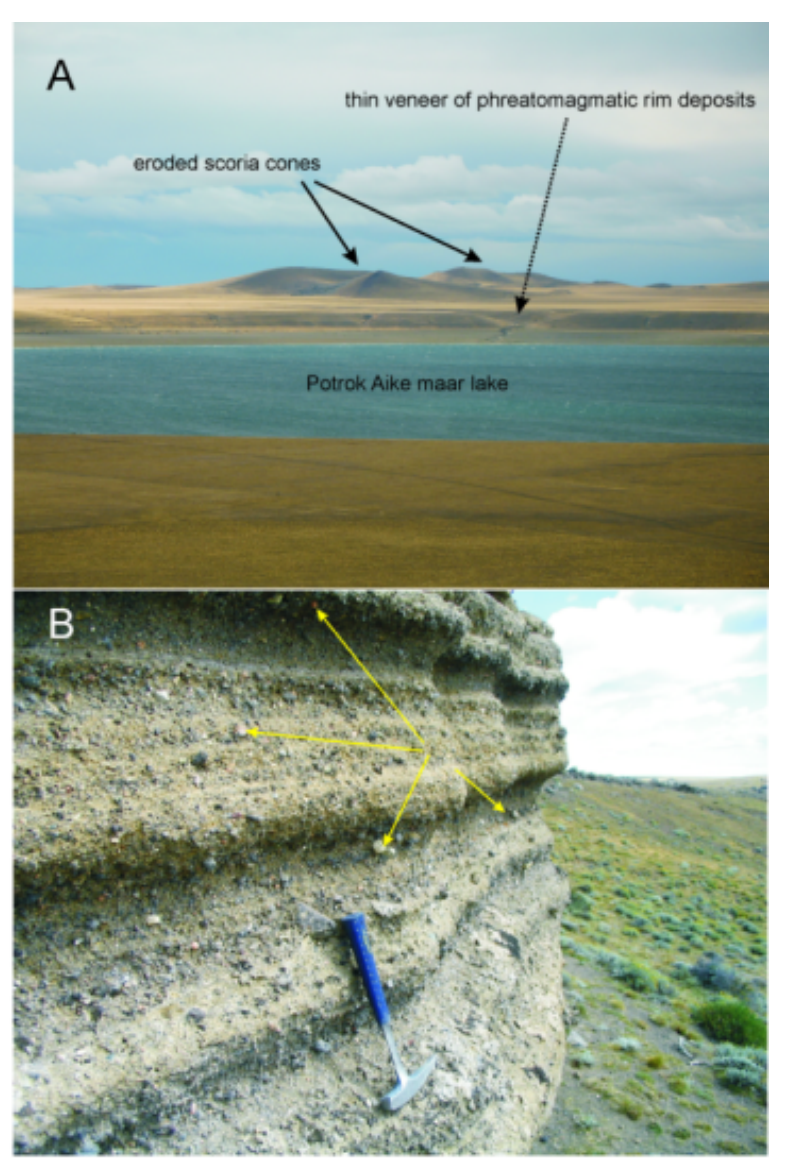
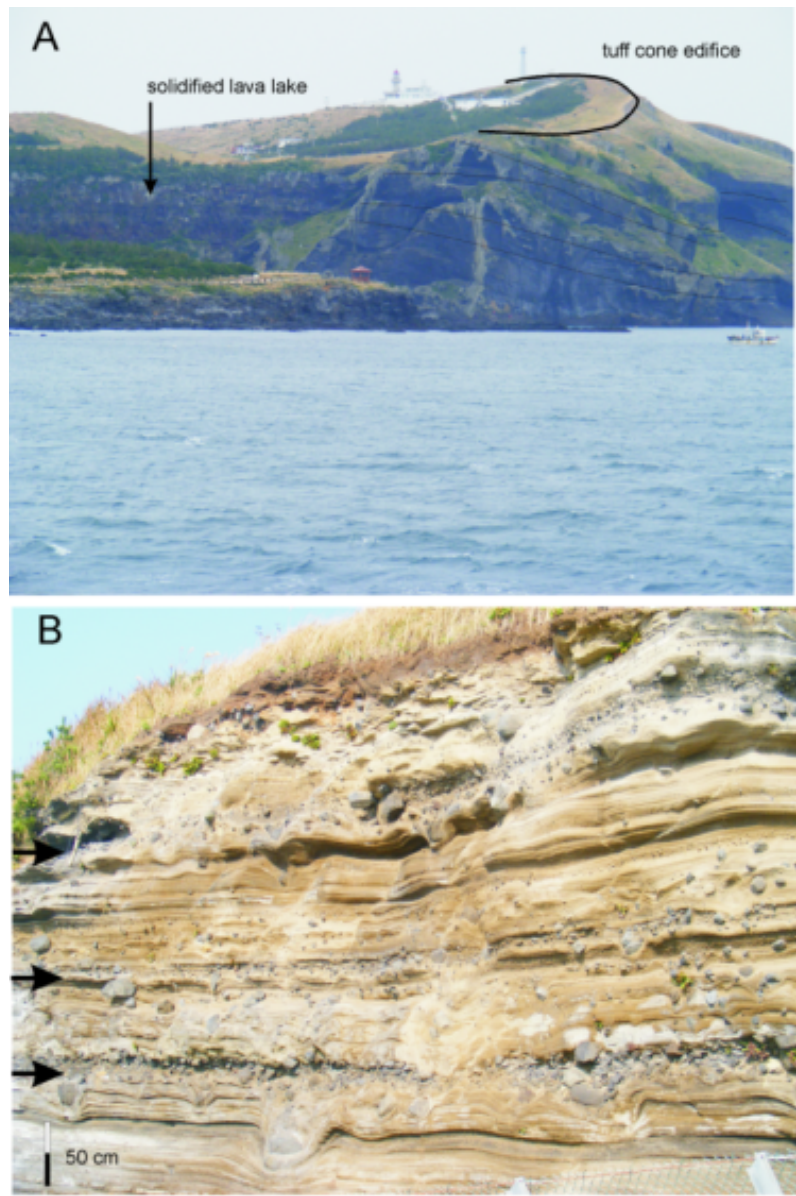

Figure 8. One of the largest (about $2 \mathrm{~km}$ across) maars of the Pali Aike Volcanic Field (PAVF). The tephra ring of the maar is poorly preserved, regardless of its relatively young age ( $\sim 0.7 \mathrm{Ma})$. Strong winds have completely removed the tephra ring in the most part. In the distance, eroded but less than a million years old scoria cones can be seen. A typical phreatomagmatic proximal pyroclastic succession of the PAVF consist of abundant fragments from coarse and fine grained soft-substrate from the underlying thick fluvio-lacustrine to glacial deposits (white arrows point to a few larger gravels).

land, well-drained alluvial plain environments in which phreatomagmatic volcanoes erupted. The older volcanoes erupted in a time when sea level was lower than it is today [16-18]. Tuff rings' pyroclastic deposits contain over 50 vol.\% accidental lithic fragments [16] (Figure 9B). Broad wedges of volcaniclastic units around the tuff rings indicate that these volcanoes provided a significant portion of pyroclasts to the growing volcaniclastic fan that intercalated with alluvial plain and low-energy shallow marine clastic sediments [19].
Figure 9. A typical phreatomagmatic volcanic landform from Jeju Island, such as the Udo tuff cone is located along the present day shoreline. The age of the tuff cone is probably few tens of thousands of years, and its original morphology is still well-preserved (e.g. the outward sloping flanks are still visible).

Proximal phreatomagmatic successions of the Suwolbong tuff ring in Jeju consists of alternating phreatomagmatic fall and surge beds interbedded with coarse grained tuff breccia horizons rich in angular volcanic lithics from buried lava flows (black arrows). These tuff breccia horizons likely represent vent clearing, conduit wall collapse events, and even slight magmatological changes. The events can be used as markers to identify volcanic episodes in the history of the volcano.

Whereas surface water was available in each field, the phreatomagmatism was rather controlled by the watersaturation level of the immediate pre-volcanic and/or synvolcanic sediments and their aerial distribution. The comparative study of the four fields suggests that the hydrogeology of the shallow subsurface country rock is an important parameter controlling the style of volcanism. In this respect, especially in the case of the youngest and 
still active field of Auckland, any future volcanic hazard study needs to invest more in understanding the porous media aquifers beneath the volcanic field.

\subsection{Auckland Volcanic Field, New Zealand}

The city of Auckland on the North Island of New Zealand is built on an active monogenetic volcanic field containing 49 discrete volcanic vents (Figure 3). The AVF is one of the predominantly basaltic Pliocene to recent intraplate volcanic fields in the northern North Island similar in characteristics to the South Auckland and Northland Volcanic Fields [20]. The AVF lies near a major magnetic anomaly (Junction Magnetic Anomaly) in an area of possible intraplate extension behind the currently active arc system that runs through the central North Island of New Zealand $[21,22]$. The predominantly ocean island basalt type chemistry of the eruptive products is consistent with the stable to mild extensional tectonics about $400 \mathrm{~km}$ away from the plate boundary [21, 22].

A wide range of eruption styles from explosive phreatomagmatic, Strombolian to Hawaiian eruptions and effusive volcanism are represented in the $\operatorname{AVF}[7,9,10,23$ 25]. Phreatomagmatic eruptions produced tuff rings with wide craters (Figure 7A) surrounded by relatively thin crater rim deposits with gently dipping beds [7, 26], particularly similar to those gently dipping and thin, base surge and phreatomagmatic fall beds that were documented from the LHPVF [27]. Maar volcanoes are also present [25], although they are infrequent and cannot be easily distinguished from broad tuff rings due to the flat and shallow volcanic edifices, similar to those in Eastern Oregon [28]. Tuff rings are commonly overlain by scoriaceous pyroclastic deposits (Figure 10A) resulting from Strombolian style eruptions as the water supply was exhausted in the course of the eruptions $[7,29]$. This is avery typical facies architecture commonly recognized from most of the WPB's phreatomagmatic volcanoes [6] (Figure 10B). The phreatomagmatism in the AVF produced pyroclastic density currents which deposited typically fine-grained cross- and dune-bedded ash (Figure 10C) inter-bedded with coarser grained tephra units from phreatomagmatic falls [7, 29]. The volume of accidental lithic fragments (Figure 10D) and/or crystal phases derived from country rocks in the accumulated pyroclastic deposits are typical for tuff rings and broad maars formed on a so-called soft-substrate environment (sand and mud) [30]. Such an environment is believed to enhance lateral quarrying of the vent site, forming broad craters and landforms of broad tuff rings and broad and shallow maars that are difficult to distinguish [30]. The immediate shallow-level pre-volcanic rock units at Auckland are dominated by Pliocene to
Pleistocene shallow marine to fluvio-lacustrine mud, sand and silt beds of few tens of metres in thickness. Beneath these deposits are the marine siliciclastic units of the Miocene Waitemata Group [7] that are texturally similar to those rock units forming the Miocene fluvio-lacustrine successions forming the country rock units in the WPB. The state of water saturation, presence of water-filled fractures and the presence of surface water are inferred to be the main controlling parameters of the resulting types and sizes of volcanoes at AVF. In one end-member eruption style that formed entirely phreatomagmatic volcanoes such as the Pukaki maar, the magma supply is inferred to be limited (or withdrawn to greater depth and/or degassed quickly early in the eruption reducing its buoyancy) in comparison to the water-saturation and/or recharge rate of the substrate the magma encountered. Increased magma supply through limited water supply from the substrate produced shallow maars that were commonly filled with ponded lava. Substantial magma supply must have been necessary to form large volume, complex, commonly deep maar volcanoes that subsequently and gradually evolved to become scoria complexes in late stages of eruption. This also reflects the limited water availability and recharge rate of the substrate to fuel phreatomagmatism in the entire course of the eruption (e.g. Domain). These models are in good agreement with geophysical data on the modelling of maar crater morphology and shallow subsurface ponded magmatic bodies [25].

The phreatomagmatic pyroclastic rock units have a matrix rich in sand and silt sourced from the substrate of Pliocene to Recent siliciclastic (fluvio-lacustrine to shallow marine) as well as the Miocene Waitemata Group marine sediments [31, 32]. Larger juvenile bombs and lapilli are commonly cauliflower-formed, host thermally altered sand and silt, and are at times coated by mud. This demonstrates an occasional intimate interaction between intruding magma and a muddy impure coolant formed from milling of the Waitemata Group sediments.

Volcanic activity in the AVF probably began about 250000 yr BP although absolute and relative ages are poorly constrained and reliable ages are only available from a few places $[33,34]$. Past eruptions have generally been small with volumes less than $0.05 \mathrm{~km}^{3}$, yet a trend of increasing volumes and number of eruptions in the last 20000 years has become evident [35]. The most recent eruption of the Rangitoto volcano, dated at around 700 years BP, had a volume of more than $2 \mathrm{~km}^{3}$, which compares with the estimated total eruptive output of the AVF prior to the Rangitoto eruption [35]. Drilling into crater lake sediments recently identified significant volumes of ash falls from local and distal eruption sites allowing a preliminary eruption chronology of the AVF to 


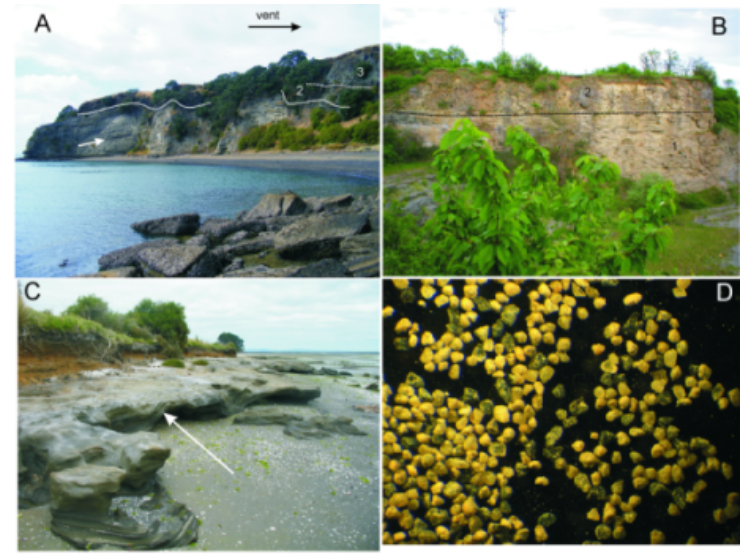

Figure 10. A coastal half section of a typical tuff ring (Browns/Motokorea Island) from the AVF. The basal part of the tuff ring rim exposes phreatomagmatic successions rich in fragments from siliciclastic, soft substrate (1). This succession gradually turns to be a scoriaceous pyroclastic unit indicating magmatically fragmented explosive eruption of the magma (2). The entire section is capped by a lava spatter unit marking complete eruption style changes at the end of the eruption. The tuff ring crater subsequently hosted a complex scoria cone.

Cross section of a tuff ring (1) crater filled with a solidified lava lake (2) from the Little Hungarian Plain Volcanic Field. The lava erupted on a crater lake floor partially filled with water rich mud (dashed line show the contact between the base of the crater and its infill) and on contact formed globular peperite and pillow lavas.

Distal base surge beds of the lhumatao tuff ring in the AVF, showing preservation about a km away from the crater. White arrow points to the undulating nature of distal base surge beds.

Ash from the Orakei Basin base surge beds rich in fragments derived from the underlying soft-substrate (yellowish grains). The fine ash fraction of the sample is particularly rich in non-juvenile fragments (yellowish grains) reaching a total volume of about 90 vol. $\%$ in extreme cases.

be established and demonstrated an average of at least one eruption in every 2500 years over the last 50000 years [8].

\subsection{Pali Aike Volcanic Field, Argentina}

The Pali Aike Volcanic Field (PAVF) covering 4500 km² is located in southernmost Argentina and Chile (Figure 4) and represents the southernmost occurrence of the Cenozoic Patagonian Plateau Lavas. Its activity (PlioceneRecent) was initiated by the formation of tabular lava flows, followed by the growth of 468 essentially monogenetic volcanic centers (tuff-rings, maars, lava spatter and scoria cones) $[36,37]$. The Cenozoic geodynamic evolution of southernmost South America is considered to re- sult mainly from convergence of the Nazca and Antarctic Plates beneath the South American Plate and transcurrent movements along the boundary between the Scotia and South American Plates. On the basis of structural and geochemical data, many workers suggest a geodynamic model that implies sub-slab asthenosphere flow through a slab window which fed the volcanic fields in Patagonia as a most likely process to generate these rocks [38-43]. However models other than slab-window generated manthe processes have also been proposed recently to explain the volcanism in Patagonia [44]. The PAVF volcanic rocks have been subdivided into three stratigraphic units [43]; older U1 age plateau-like basal lava flows, younger U2 age eroded old cones, tuff rings, maars, and associated lava flows, and the youngest unit U3, well-preserved scoria cones and lava flows. The U1, U2 and U3 units occupy 83,15 , and $2 \%$ of the surface of the whole volcanic field according to satellite image analysis [43]. The volcanic pile reaches its greatest thickness (up to $120 \mathrm{~m}$ ) in the northwestern side. More than 450 eruptive centers have been identified overlying the basal volcanic units [43]. These volcanic centers are variably eroded scoria cones, tuff rings and maars, commonly associated with $\mathrm{km}$-length "aa" and "pahoehoe" lava flows.

On the basis of 50 isotopic age determinations (K-Ar and $\left.{ }^{40} \mathrm{Ar}-{ }^{39} \mathrm{Ar}\right)$, timing of volcanism ranges from 3.78 to $0.17 \mathrm{Ma}$ for the Pali Aike Volcanic Field [43] and therefore the PAVF should represent an analogy to the intial erosional stages of the WPB volcanic fields. However, the older PAVF ages are similar to those measured from the WPB's younger evolutional stage. The PAVF is clearly older than the AVF, and therefore the PAVF can provide a good analogy to compare the potential erosional stages of phreatomagmatic monogenetic fields.

The orientation of the volcanic vents has been studied by many workers who identified a strong structural control on the distribution of the vents [37]. Such strong structural control is not known from the WPB and AVF, however some lineaments are evident. At the PAVF, both the cone alignment and the basal elongation of the cones show characteristic NW-SE and ENE-WSE trends (Figure 4), with a minor NS trend making these lineaments at PAVF an immediately recognizable feature [37].

The volcanoes of the PAVF erupted onto the thick sequence of siliciclastic and pelitic sediments of the Magellan Basin [36]. These sediments represent the basin infill of the Austral Patagonian rift, the southernmost part of NW-SE continental rifts that have developed since Late Triassic time due to extensional tectonics linked to Gondwana break up [36]. The youngest deposits in the rift basin are fluvio-lacustrine units intercalated with pyroclastic and glacial sediments of Late Miocene to Holocene 
age. These sediments form the upper few hundred metres of the subsurface stratigraphy, and fragments from these units are abundant in the preserved pyroclastic rocks in every location of the PAVF.

Pali Aike Volcanic Field (PAVF) is one of the best examples of volcanic fields dominated by shallow, broad and low-rimmed phreatomagmatic volcanoes $[45,46]$ (Figure 8A). The PAVF is a field comparable to the WPB monogenetic volcanoes with respect to the inferred phreatomagmatic eruptive history of most of their vents followed by subsequent magmatic explosive and effusive phases. The lack of vegetation cover at the PAVF allows us to observe the various erosion stages a flat and broad tuff ring and associated shallow maar can suffer over few millionyear in an area characterised by strong wind, low-rainfall and grass or no vegetation cover. In addition dramatic shifts in climatic conditions (e.g. from dry to wet) also have been recognized in the Pannonian Basin since volcanism ceased [47-51]. Such environments were envisioned in the final stages of the WPB volcanism [52], and after volcanism ceased and therefore the PAVF could be looked at as a good site to envisage the erosional stages the WPB volcanoes likely went through reaching their present day morphology. At PAVF the average rain fall is currently less than $100 \mathrm{~mm}$ a year, and this value is likely to be similar at least in the past million years, when the majority of the PAVF volcanoes had formed. The low rain fall with the steady westerly high speed wind (commonly reaching over $100 \mathrm{~km} \mathrm{~h}^{-1}$ ) only allows a closed grass vegetation in the region, that homogeneously coversthe volcanic landforms.

At PAVF, due to the closed vegetation cover, good tephra ring sequences are rare, and only exist in the steep inner cliffs of some larger maars. Small and broad, shallow tuff rings are often covered with shallow lakes (Figure 4) that are extremely similar to lakes developed on a deflation basin. Existence of maar and tuff rings is commonly interpreted only on the bases of shallow geophysical methods and some morphological analyses of the landscape. However, clear identification and/or description of tephra units surrounding shallow (commonly lake filled) depressions that are characteristic of phreatomagmatic volcanic origin are rare. Recently some effort was made to describe the preserved and exposed pyroclastic sequences of tuff rings with an aim to characterise the magma fragmentation style, eruption duration and landscape evolution of a maar-pitted volcanic field. The main characteristics of most of the PAVF volcanoes is their shallow, broad dish-like craters commonly filled with lakes such as Potrok Aike (Figure 4), that has recently been a subject of a multinational, interdisciplinary research [53-55]. Other flat, and shallow maars are known along the Argentine
- Chilean state border, forming alignments of volcanoes commonly filled with shallow saline lakes and skeletonlike lava spatter-dominated scoria cone remnants. Evidently the majority of the studied tephra ring pyroclastic successions demonstrate the presence of abundant country rock fragments and their mineral phases as accidental lithic and/or lithic-derived minerals derived from underlying fluvio-lacustrine and glacial deposits forming the basin-fill successions at PAVF (Figure 8B). The presence of these clasts in the pyroclastic rocks is inferred to be the evidence of maar-forming volcanic eruptions through a "soft rock" environment. The morphological appearance and the abundance of rock fragments from the porous media aquifer (soft-substrate) at PAVF are similar to those volcanoes located in the LHPVF.

\subsection{Jeju Island, Korea}

Jeju Island (also Jeju-do, "do" meaning "island" in Korean, or Cheju or Cheju-do prior to the Revised Romanisation of the Korean script in 2000) is a volcanic island off the coast of South Korea in the East China Sea (Yellow Sea) at the western entrance of the Korea-Tsushima Strait (Figure 5). Jeju Island is one among several intraplate volcanoes in continental NE Asia that has been active during the Cenozoic [56]. The island consists of a stratovolcano/shield-type polygenetic central volcanic edifice with its surface and surroundings dotted by over 300 monogenetic eruptive centres, mainly scoria cones and minor tuff rings, maars and lava domes. Many more volcanic centres are buried or submerged. Jeju Island is surrounded by c. 100 metres-deep water [57] on the continental shelf of the Amurian Plate [58-60], which is the same plate as the rest of the Korean peninsula. An overall WSW-ENE compressional and NNW-SSE extensional regime exists in the southern part of the Korean peninsula [58-60], and this has been suggested for Jeju in order to explain volcanic centres alignments [61] however, such alignments are not as prominent as at PAVF.

Thorough understanding of the subsurface geology of the island has been gained thanks to thousands of groundwater bores drilled over the past fifty years [57]. These have revealed that the basement of granitic, metamorphic and felsic volcanic rocks is overlain by a 70 to $250 \mathrm{~m}$ thick submarine and subaerially emplaced, unconsolidated quartzose sandy and muddy sediment named $U$ Formation. This was deposited on the continental shelf prior to the onset of volcanism [57]. The commencement of volcanism on Jeju is recorded in the c. $100 \mathrm{~m}$ thick Seoguipo Formation, which is composed of primary and reworked, subaerial and submarine, Early to Middle Pleistocene (1.8 to 0.8-0.4 Ma) hydrovolcanic/phreatomagmatic deposits and 
intercalated marine and non marine fossiliferous sedimentary sequences and soil horizons [17, 18, 62]. Moreover the JVF basement and volcanic rock units form a complex succession with many fractured hard rock units that likely act as fracture-controlled aquifers. It seems that in Jeju the country-rock lithologies provide potential combined aquifers, which are similar to those inferred for the Bakony- Balaton Highland Volcanic Field (BBHVF) in the WPB [63].

Facies and erosional surfaces within the Seoguipo formation can not be correlated laterally even over very short distances (few hundred metres), and subaerial and submarine facies associations are intercalated randomly [17]. Such a scenario is very similar to our current understanding of the immediate pre-volcanic stratigraphy at the WPB volcanic fields. In the Jeju case this was interpreted to indicate episodic explosive volcanic/hydrovolcanic activity during Quaternary glacial-interglacial seal level fluctuation rather than tectonically controlled uplift and subsidence [17]. In the case of the WPB volcanoes, we know very little about the syn-volcanic non-volcanic deposition and basin evolution of the WPB. Due to the older age of the WPB, lateral correlation is nearly impossible due to the dissected and fragmental nature of preserved prevolcanic sedimentary units. These may represent any sort of fluvio-lacustrine sedimentary environment active during the volcanism. In this respect, Jeju could be viewed and potentially used as an alternative to help identify key locations at WPB to characterise syn-volcanic sedimentary events, a research subject that has not yet been targeted.

Surveys of numerous groundwater bore holes in Jeju however, revealed that the upper surface of the Seoguipo Formation is irregularly distributed throughout the island, generally more elevated in the central part of the island (between $50 \mathrm{~m}$ below and $50 \mathrm{~m}$ above sea level), whereas it becomes deeper in the eastern and western sides (c. 50$100 \mathrm{~m}$ below seal level) [64]. As early tuff cones (pre-lava shield stage) are grouped into the Seoguipo formation, the upper surface is very irregular [57]. The Pyosunri basalt, which forms the bulk of the island lava plateau [65] is c. 50-150 m thick in coastal regions [17]. It was erupted contemporaneously with volcaniclastic deposition of the Seoguipo Formation, as some of the volcanic vents protrude through the plateau-forming lavas [18]. Minor trachyte and trachyandesite lava flows are also intercalated within the sequence, which was then overlain by the intermediate volcanic rocks that form the Halla strato/shield volcano (Figure 5) and by over 300 scoria cones [65].

Early to Middle Pleistocene hydrovolcanic centres developed multiple superposed tuff rings and cones as a consequence of vent collapse and migration due to the instability of the unconsolidated sedimentary substrate such as the $U$ and Seoguipo Formations [66]. In contrast, Holocene centres formed over stable plateau-forming lavas and have more definite morphologies [66]. It is important to note that monogenetic eruptions forming scoria cones and hydrovolcanic centres have occurred throughout the volcanic history of Jeju Island, and are therefore not solely a surface and recent expression of volcanism $[17,57]$. The type and size of the phreatomagmatic volcanoes also indicate the probable influence of combined aquifers similar to those known from the BBHVF in Hungary [63].

The number of vents and the small-volume monogenetic volcanism associated with extensive lava fields, as well as a large central volcano and the presence of evolved mostly trachytic dome and lava systems are very different characteristics of Jeju in comparison to the WPB volcanic fields. However, the preserved volcanic landforms are similar and comparable to the larger eruptive centres of the WPB. Particularly the volcanic centres of the WPB that are inferred to have been erupted in areas where the pre-volcanic rocks units are thick siliciclastic basinfilling sediments, such as the case in the Little Hungarian Plain Volcanic Field, show great similarity to the Jeju phreatomagmatic volcanoes. The relatively short duration of Jeju volcanism $(<2 \mathrm{Ma})$ in comparison to the lifespan of the WPB volcanism (at least $6 \mathrm{Ma}$ ) [67], and the great diversity of volcano types are key differences between Jeju and WPB. However, the texture of the preserved pyroclastic rocks and their 3D facies architecture can be successfully used to envisage the preservation potential of phreatomagmatic volcanoes formed due to explosive fragmentation of magma interacting with abundant surface and/or soft-substrate-hosted as well as fracture-controlled ground-water. The combined aquifer nature of the country rocks of the BBHVF (e.g. karstic aquifers covered by porous-media aquifers) and the potential for ground water sources to fuel phreatomagmatism are the main similarities to the JVF. Instead, the increasing thickness of the porous-media aquifer cover over fractured hard rock from the BBHVF toward the LHPVF in Hungary bears more similarities to the potential ground-water sources of the AVF.

\section{Soft-substrate Environment and its Potential Influence on Magma Fragmentation and Deposit Charac- teristics}

A combination of two hydrologically distinct aquifers may help to develop complex maar/tuff ring volcanoes $[63,66]$. Large eruption rate and abundant water supply from near 
surface aquifers often lead to vent migration and lateral excavation of the volcanic conduits resulting in the development of a chain of volcanoes [68]. The general abundance of clasts from near surface, commonly fluviolacustrine clastic units, in the pyroclastic rocks indicate a soft rock environment through which phreatomagmatic volcanoes erupted and formed "champagne-glass" shaped maar/diatremes $[69,70]$. The morphology of maar and tuff ring volcanoes in such settings are generally flat, and their deposits may cover large areas, but as thin veneers only $[69,71]$. Crater rim deposits in such environments are easily eroded because: 1) they are generally fine-grained and composed dominantly of mineral phases (quartz, mica, clay minerals etc.) that are non-resistant to erosion, or; 2) they are easy to breach by fluvial systems, often the host environment where the volcanoes erupted (e.g. Nilahue maar, Rininahue, Chile). Volcanic fields in arid, high wind, low vegetation areas are extremely sensitive to such conditions, and crater rim deposits are preserved in wind shadows. However, in such conditions vegetation such as grass can be a very effective cover over thin tephra units, homogeneously masking the landscape with grass cover.

Specific rock textures preserved in phreatomagmatic successions can provide vital information on the style of magma - water interaction and eventually the type of external water sources that may have been involved in phreatomagmatism. Mixing and mingling textures of magma and host, unconsolidated, water-saturated sediments are important to understand the nature of the magma and water-saturated sediment interaction prior the explosive fragmentation that formed the pyroclasts. Peperites commonly form when magma intrudes wet unconsolidated sediment [72]. The host can be any clastic sediment, and a great variety of interactive phenomena occur under a wide range of physical conditions [72]. They are the result of mildly explosive or non-explosive magmawater interaction in small-volume phreatomagmatic volcanoes. In general, peperites are considered to be very common in arc-related and other volcano-sedimentary sequences associated with composite volcanic systems. In such settings peperite and associated volcaniclastic sediments may form large volume deposits of a very diverse textural and compositional range, from rhyolite to basic rock types. Peperites and their associated volcaniclastic environment are important in reconstructing paleoenvironments. It has been recently recognized that peperite and the associated pyroclastic environment are as common in small volume phreatomagmatic vent-filling deposits and/or along the contacts between sediment and mafic, generally small-volume intrusions and lavas as in more complex stratovolcanoes and or caldera volcanic systems [73].

In the Pannonian Basin, a wide range of peperite has been described lately in phreatomagmatic, small-volume mafic volcanic systems [73] (Figuref 11A). The recognition of the existence of peperite in small-volume, phreatomagmatic volcanoes and their associated intrusive/effusive products highlights the importance of identification of such textures and the interpretation of their meaning in these types of volcanoes.

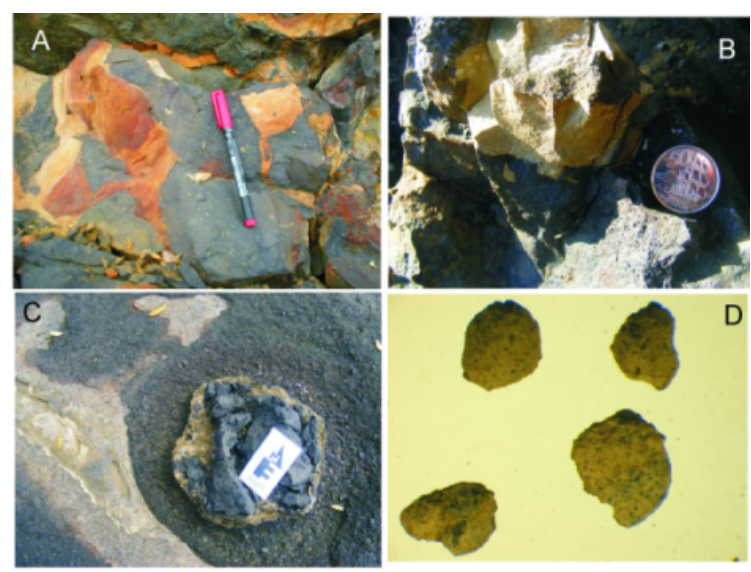

Figure 11. Blocky peperite from an exposed diatreme from the BBHVF (Hajagos) representing the "frozen coarse mixing" of magma and wet soft-substrate.

Blocky peperitic domain, as a pyroclast hosted in tuff breccia of the Orakei maar at the AVF suggesting premixing stage of magma and wet substrate. Prior to mixing the mixture has been fragmented and erupted through the vent.

Cauliflower shape bomb with mud cover from AVF suggesting active mixing processes between melt and softsubstrate prior fragmentation.

Fine ash (particles are about $0.5 \mathrm{~mm}$ across) particles from the Orakei maar (AVF) phreatomagmatic pyroclastic succession, showing fine mud coating, indicating abundant mud in the transporting agent base surges from where fine dust could have adhered on the surface of the volcanic glass particles.

Peperite is often described on the basis of the juvenile clast morphology as blocky or fluidal, but there is a big range in shapes that have to be taken into account. The shape differences are often explained by the simple textural differences of the host deposit as fine- and/or coarsegrained texture that may produce globular and/or blocky peperite respectively $[73,74]$. However, examples from the phreatomagmatic volcanic fields in the Pannonian Basin show that this simple classification is not the only controlling parameter. This has been interpreted as a sign of the complex water saturation stage of wet pyroclast mixtures in the vent/conduit zone as well as the soft-substrate. While peperites are evident in the eroded WPB volcanoes, such zones are not exposed in the young fields studied here. In the young volcanic fields, however, lava and sed- 
iment mixing (Figure 11B), plastically deformed sediment (mud) lumps (Fig. 11C) as well as abundant sediment coating and/or coring (Figure 11D) show evidence of effective coarse mixing of magma and wet soft substrate, and eventual subsequent fragmentation and disruption of peperitic zones providing bomb to block size peperitic domains as fragments in the accumulating pyroclastic successions.

\section{Relevance to Mio-Pleistocene Volcanic Fields in the Pannonian Basin}

\subsection{Volcanic Landforms}

Numerous examples of intra-continental volcanic fields that evolved in a low-lying fluvio-lacustrine basin show irregularities when their erosional history is reconstructed. In this context phreatomagmatic processes dominate the fragmentation history of the rising magma. Volcanism in the western segment of the Pannonian Basin, Hungary in the Carpatho-Pannon region (Figure 1) occurred during the Miocene and Pleistocene between 7.98 and 2.3'Ma [67, 75-77]. In the Bakony - Balaton Highland Volcanic Field (BBHVF) (Figure 2A), different volcanoes can be grouped together by their space-time relationship. Dominant volcanic landforms in the western Pannonian Basin are variously eroded maars, tuff rings, scoria cones, and shield volcanoes [6]. However, original volcanic landforms are not preserved, and the only information we can gain on the potential eruption mechanism is based on the preserved proximal to crater and volcanic conduit filling successions.

In the western Pannonian Basin, the basement of the Bakony - Balaton Highland Volcanic Field (BBHVF) consists of Silurian schists, Permian red sandstone and Mesozoic carbonaceous beds [78] (Figure 2B). The basement of the Little Hungarian Plain Volcanic Field (LHPVF) is composed of Palaeozoic to Mesozoic metamorphic rocks [79]. These rock units are about tens to hundreds of metres below the surface, and in many cases act as good fracture controlled aquifers with complex and not fully understood hydrology [78]. In each area the immediate underlying rock units in the WPB volcanic fields comprise variable thicknesses of Miocene quartzofeldspathic siliciclastic sediments deposited from a shallow marine to fluvio-lacustrine environment [78, 80-83] very similar to the siliciclastic units forming the immediate pre-volcanic country rock strata of AVF, PAVF and JVF. The bedrock hydrogeological characteristics are inferred to have strongly influenced the morphology of the overlying volcanic landforms forming broad and shallow maars and tuff rings similar to those forming the majority of the phreatomagmatic volcanoes of the AVF. While the original volcanic landforms in western Hungary are strongly modified and cannot be investigated directly, the abundance of siliciclastic rock fragments in the preserved pyroclastic rocks indicates significant and potentially laterally expanding crater excavation $[30,84]$. In addition, $3 \mathrm{D}$ reconstruction of volcanic rock facies distribution of phreatomagmatic volcano remnants in the LHPVF confirmed the presence of laterally extensive, lensoid shape volcanic bodies, closely resembling very broad and shallow maars and tuff rings similar to those in Auckland such as e.g. Panmure or Orakei Basin [31, 32] (Figure 3). Volcanic landforms of the PAVF are also similar to those known from Auckland and can be inferred to represent an erosional stage of phreatomagmatic volcanoes between the AVF and the WPB.

\subsection{Monogenetic, Polycyclic Monogenetic, Polymagmatic Polycyclic Monogenetic and Polygenetic Volcanism}

Monogenetic volcanoes are traditionally referred to as those volcanoes that erupt only once during their eruptive history [85, 86]. They are small and occur as scoria cones, tuff cones, tuff rings, and maars [85, 87, 88]. They form from typically short-lived single and brief eruptions [86]. Their characteristic feature is that the duration of the eruption is usually shorter than the solidification time required for the feeding system to provide the melt for the eruption $[86,89]$. This definition maybe useful to classify volcanoes that erupt mafic magmas and produce small-volume cinder cones associated with variably long lava flows.

Given that phreatomagmatic volcanoes such as maars and tuff rings are considered to be the wet equivalent of scoria cones [3], a general preconception of the short eruption durations of phreatomagmatic volcanoes is accepted. Eyewitnesses of a few historic maar volcanic eruptions such as Ukinrek (Alaska) [90, 91] and Rininahue (Chile) [92] support the working hypothesis that such eruptions usually last a short time. Calculation of the necessary melt involvement in such eruptions commonly gives a very low proportion of primary magma needed to create such volcanoes [93-97]. This conclusion is supported by the component analyses of phreatomagmatic tephra in many places in various volcanic settings. To solidify such small volumes of melt in the feeding system it may need less thana few days or weeks $[86,98]$. Conversely, there are reports from scoria cones which show gradual transition toward composite volcanoes. Such volcanoes are especially common 
features in the Transmexican Volcanic Belt, and they are hard to classify in terms of monogenetic and polygenetic systems. On the basis of historic eruptions it is clear, that most of these volcanoes are large in volume and the deposited tephra commonly consists of a great diversity of eruptive products from strikingly different fragmentation histories of the melt (e.g. magmatic vs. phreatomagmatic). Especially, phreatomagmatic volcanoes are often associated with scoria cones, spatter cones and lava flows and they form together a volcanic complex. Such volcanic complexes are closely spaced individual volcanoes that individually may fulfill the requirement of the sensu stricto term monogenetic. However, to identify these features in older and eroded settings such as the monogenetic volcanic fields in the WPB in Central Europe may be problematic if not impossible.

It seems that the differences between composite and monogenetic volcanoes may be nothing other than the total eruptive product produced by a volcanic system and/or the total number of vents, the stability of the feeding system, and perhaps the source region of the melt involved in the eruptions. Therefore the following simplified classification can be used:

Sensu stricto monogenetic volcanoes are volcanoes with small eruptive and edifice volume with a single vent erupted once in a short time;

Polycyclic monogenetic volcanoes are volcanoes with slightly laterally shifted single and/or nested vent complexes, each producing a small-volume of eruptive products and buids a small volcanic edifice in well separated eruptive episodes, each documenting short eruption duration, however, the total lifespan of the volcano could be long. This type of volcano could be sub-grouped into 1) nested polycyclic monogenetic volcanoes, where the vent for each eruption cycle is distinct but located more or less in the same position, and 2) dispersed polycyclic monogenetic volcanoes, which have vent sites that are distinctly separated by distances comparable to the half-width of one of the individual volcanic edifices produced, such as the Albano maar lake in Italy [99].

Polymagmatic polycyclic monogenetic volcanoes are volcanoes that are the same as the polycyclic monogenetic volcanoes, but in addition they having chemically distinct eruptive products, potentially associated with distinct eruptive episodes.

Polygenetic volcanoes then would be those where the melt source is relatively stable over prolonged period (yrs to kyrs), where shallow magma storage systems are expected to develop, and form a well-defined and stabile vent zone over a long time, and produce obviously large volumes and potentially chemically diverse eruptive products. The volcanic fields of the WPB contain large volume erosional remnants of phreatomagmatic volcanoes with capping magmatic infill (Figure 6). Thick initial phreatomagmatic pyroclastic rock successions are common however in these large volume erosional remnants. These depositscommonly contain well-defined eruptive packages divided by explosion breccias rich in deep-sourced nonvolcanic lithic clasts (Figure 12A) and/or abundant plastically deformed fragments from the immediate underlying soft-substrate siliciclastic rock units (Figure 12B). Due to the proximity of the preserved sites to the vent(s) unconformity surfaces, quickly changing bedding orientations and presence of localized explosion breccias are not conclusive evidence of multiple eruptive episodes. They can also reflect vent instability processes. However, large and extensive (kilometre-scale) volcanic buttes, such as e.g. Fekete-hegy and Tihany (Figure 2) in the BBHVF are the likely candidates for phreatomagmatic volcanic complexes with multiple vents. These probable long lasting eruptions could be classified as nested and/or dispersed polycyclic monogenetic volcanoes, potentially having also polymagmatic nature. To visualise the original volcanic landforms and the eruptive processes that may be able to create such volcanic architecture, young volcanic complexes need to be compared. At the AVF, large phreatomagmatic volcanoes with magmatic infill such as Crater Hill, Three Kings or Panmure Basin (Figure 3) are comparable in size to the WPB large and complex volcanoes. In spite of the size similarities ( $\mathrm{km}$-range crater diameters), the magmatic infill of the above mentioned AVF volcanoes is predominantly lava spatter and scoria cone(s) with minor lava plugs. These volcanoes are the likely candidates to envisage the original volcanic landform of the volcanic complex of Tihany in the BBHVF, where capping lava represents only a minority of the eruptive products. Lava lake-filled large and apparently multiple vent and nested maars are more common in the PAVF [46]. The nested nature ("maar in a maar") of the well-preserved shallow maars of the PAVF, with common multiple scoria cones and lava infill (Figure 12C), are potentially the best modern analogues for the large volcanic complexes of the WPB volcanoes.

It can be concluded that the majority of the volcanoes at the WPB volcanic fields are monogenetic, however polycyclic eruptions, as defined from cones from Nevada $[98,100]$, are likely to have formed the nested volcanic complexes similar to the larger volcanic complexes of the AVF and PAVF. True polygenetic volcanoes, such as the central volcano (Mt Halla) on Jeju Island, are not known from the WPB volcanic fields. The largest volume lava shields such as Agár-tető and Kab-hegy (Figure 2A) 

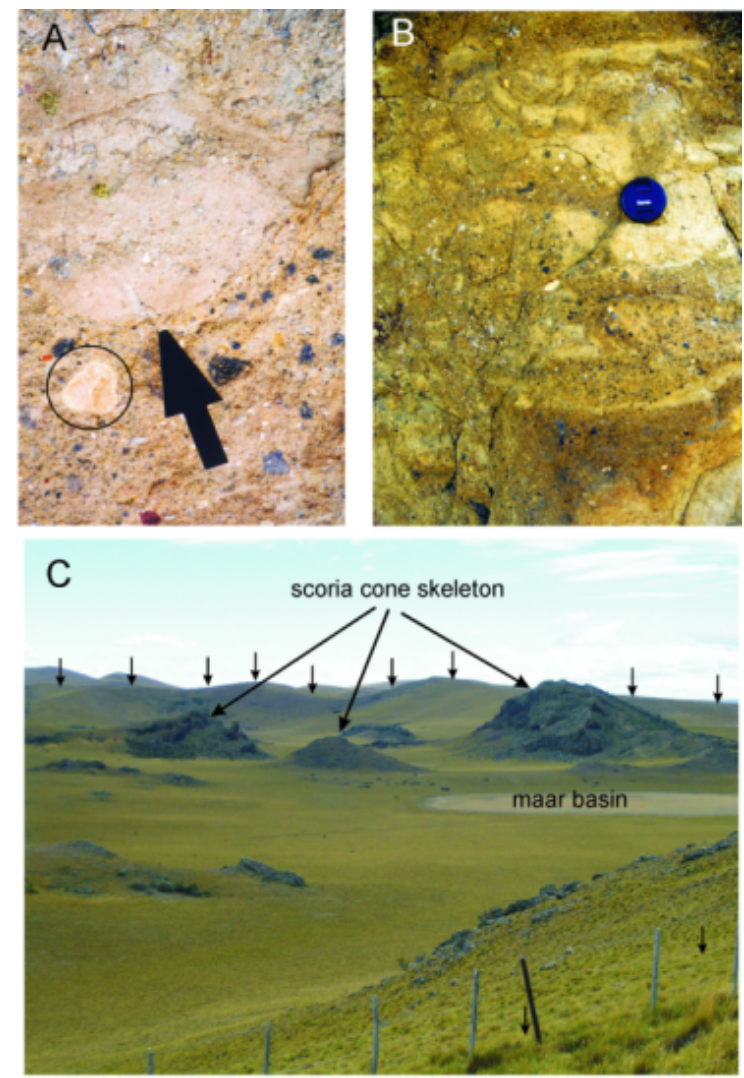

Figure 12. Accidental lithic clast rich pyroclastic rock unit from the BBHVF. Note the hard rock (circle) and recycled tuff fragment (arrow) in the chaotic, massive lapilli tuff/tuff breccia unit. The fine matrix of the rock however rich in siliciclastic fragments derived from the immediate underlying soft-substrate indicating mixed country rock control on the phreatomagmatic eruptions.

Accidental lithic fragments of plastically deformed mud in the basal phreatomagmatic successions of Szigliget diatreme of the BBHVF, indicating interaction between magma and wet soft-substrate.

Nested shallow maar/tuff ring and scoria cone complex from the Pali Aike Volcanic Field. Note the broad shallow maar crater (small arrows point to the crater rim), and the skeleton-like scoria cones in the crater.

of the WPB volcanic fields are large only in comparison to the individual volcanic volumes of these fields. These shields are certainly formed over millions of years as has been demonstrated from $\mathrm{K}-\mathrm{Ar}$ radiometric ages [76, 101] and volcanic stratigraphy, and formed in distinct volcanic episodes. Each episode however produced relatively small volume lava effusion, and therefore these volcanoes would still be best classified as polycyclic monogenetic volcanoes in the same manner as Rangitoto (Figure 3), in the AVF [8]. In addition, Rangitoto also demonstrated distinct magma types involved in its eruptive episodes, indicating polymagmatic nature (IEM Smith pers. com.). The polymagmatic nature of monogenetic eruptions at large volume phreatomagmatic volcanoes with magmatic infill has recently been recognized from Jeju [102] and the model potentially needs to be tested at the WPB in the near future. Such magmatological study has not been performed yet either from Agár-tető or from Kab-hegy, and at this stage these lava shields cannot be further characterized.

\subsection{Pyroclastic Facies Architecture and Preservation Potential}

One of the distinct features of the erosion remnants of small-volume basaltic volcanoes of the WPB is their general complex architecture. Proximal phreatomagmatic pyroclastic successions are commonly topped by late magmatic explosive and effusive products (Figure 13A). Also, phreatomagmatic successions are commonly inter-bedded with distinct accidental lithic clast rich horizons, inferred to represent event horizons associated with vent clearing. Nearly all the known erosion remnants of the WPB are complex volcanoes (even the small volume ones) where the gradual eruption style changes over the eruption time. The remnants are recorded in a gradual so-called "upward drying" phreatomagmatic sequence, which gradually or abruptly becomes a pyroclastic unit representing eruptions driven by purely magmatically fragmented explosive processes (Figure 11B). Also, at the WPB volcanic fields, nearly all of the preserved erosion remnants are capped by a thick lava unit inferred to represent solidified lava lakes. Because of the older age of the WPB volcanoes, and consequently their erosion-modified volcanic landforms, it can only be inferred that they are remnant of various maars surrounded by tuff rings that were filled by subsequent scoria and lava spatter cones as well as lava lakes. The AVF is a perfect place to visualise the above mentioned scenario.

The AVF consists of shallow maar volcanoes and tuff rings. Nearly each one of them is filled with at least a smallvolume of lava spatter cones, or a fairly large scoria cone (Figure 13B). Complete infill of a phreatomagmatic crater by a lava lake is rare at the AVF, however, a magmatic plug or irregular surface textured minor lava lakes, usually associated with fissure sources, are common. The initial tuff ring sequences of the AVF are easily examined in their proximal to distal sections (where exposures allow it), and a "triplicate" set of pyroclastic facies architecture is apparent. The basal layers are commonly rich in plastically deformed mud and silt, many of them thermally altered, but not baked. These pyroclastic breccias are usually not more than 5 metres thick such as the Orakei Basin (Fig- 


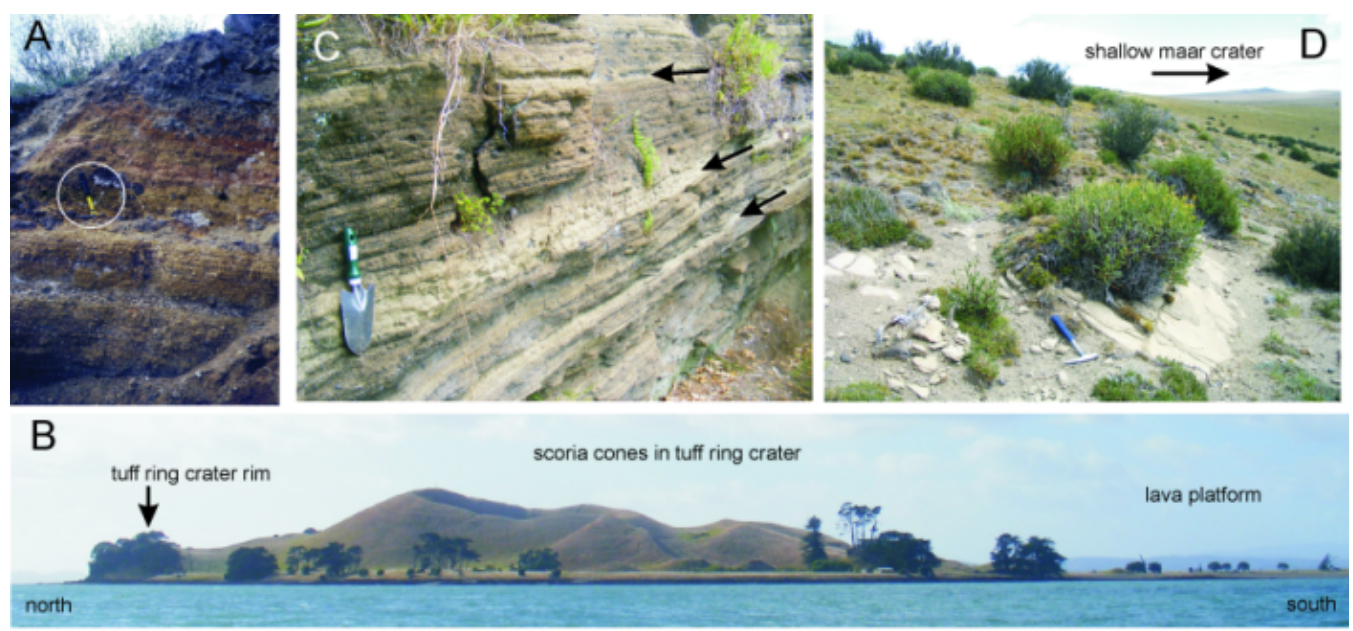

Figure 13. Gradual transition from phreatomagmatic to magmatic pyroclastic rock units at Haláp, BBHVF.

The upper section of the tephra rim deposits of the Orakei maar/tuff ring consist of alternating beds of pure phreatomagmatic (arrows) and more magmatic fragmentation dominated beds suggesting a gradual drying out of the soft-substrate in the course of the eruption.

Shallow maar from the Pali Aike Volcanic Field with accidental fragment-rich ash plastered in its internal crater wall.

Brown/Motokorea Island tuff ring is a typical volcano from Auckland, exhibiting incomplete phreatomagmatic tephra rim and crater filling scoria cone complexes indicating a gradual shifting from phreatomagmatic to magmatic explosive and effusive events in the course of the eruption, as a sign of gradual cut off from external water access to the rising magma.

ure 3) tuff ring sequence (Figure 7B). Above this initial vent opening phase-related units, a more regular coarsefine base surge and associated phreatomagmatic fall deposited successions can be identified (Figure 13C). These types of units form the bulk of the exposed phreatomagmatic pyroclastic successions at Auckland. In this succession however, there is sedimentary evidence of slight changes and shift of eruptive styles, or minor magmatically fragmented fall deposits reflecting rapid changes of magma and water interaction styles, external water availability and/or conduit processes. It is relatively rare to see evidence of explosion locus downward migration in the preserved pyroclastic record; however this might be just the reflection of the relatively uniform texture of the immediate pre-volcanic country rocks. Interestingly, the subsequent magmatically fragmented magmatic capping units are rather abruptly developed over the initial phreatomagmatic successions in each of the known location (Figure 11B). However a gradually increasing number of pyroclastic beds that were magmatically fragmented are evident in most of the locations. This facies-change from phreatomagmatic to magmatic capping unit at AVF is very similar to the scenario known from the WPB volcanic fields.

In both fields, at AVF and WPB the juvenile pyroclasts are typical for phreatomagmatically fragmented magma such as blocky, micro-fractured and complex glass shards with low vesicularity and microlite content. At WPB, however, the larger, non-interactive glassy pyroclasts are more microlite and microphenocryst-rich in comparison to the samples from AVF.

The Jeju pyroclastic rock successions also reflect some gradual changes from initial phreatomagmatic successions to magmatic capping units. At Jeju, while accidental lithics are common, they are not as high in the total volume of the pyroclastic rocks as in the case of AVF and WPB similar pyroclastic units. Also, the juvenile pyroclasts at Jeju are more vesicular, and they are highly microliterich. The Jeju pyroclastic rock textures commonly indicate clearer vent conditions and therefore magma and pure surface and/or near surface water explosive interactions. In this regard, the Jeju pyroclastic rock units share more common features to those preserved in the LHPVF than those forming the volcanic erosion remnants of the BBHVF.

At Auckland, the present day exposures permit only the pyroclastic successions forming the constructional parts of maars and tuff rings (and their late magmatic infill) to be seen. A similar situation is valid for Jeju, however, the large coastal sections also provide perfect half sections of tuff rings and tuff cones, exposing their proximal facies. 
In contrast to AVF and Jeju, the WPB's volcanoes almost exclusively preserve the core of former phreatomagmatic volcanoes and their late magmatic cap. The present day erosion level therefore exposes the sub-surface architecture of these volcanoes and allows access to crater and conduit filling pyroclastic successions in half sections. In these successions, representing the diatremes of maar volcanoes, peperites are common, reflecting an active coarse mixing of rising/intruding magma into wet "soft-sediment" and/or crater and/or conduit-filling wet pre-volcanic sediment and pyroclast mixtures. Common cored bombs, complex cauliflower bomb and lapilli with irregularly shaped mud and silt chunks (Figure 10D) as well as larger blocks with complex magma and wet sediment mingling and mixing are common clast types throughoutthe phreatomagmatic successions of the AVF volcanoes. It is reasonable to infer that these clasts are disrupted peperitic domains, similar to those exposed in situ in the WPB's diatremes. Interestingly similar peperitic domains are rare from Jeju, further indicating that at Jeju the magma-water interaction occurred in open went conditions, typical for tuff cone forming eruptions.

The pyroclastic successions of the PAVF are similar to those exposed at the WPB, however, the reserved tephra rim deposits are commonly thin and poorly exposed to allow more detailed conclusion on their texture, cyclicity, or lateral facies variations. However, it seems that many of the phreatomagmatic successions at PAVF are wellbedded and rich in accidental lithic clasts, especially in their proximal settings. In medial to distal facies they are very fine-grained (Figure 13D), dominated by mineral phases derived from siliciclastic county rock units. So far no abundance of peperitic domains as clasts in the phreatomagmatic successions has been identified at the PAVF. This scenario indicates that the PAVF phreatomagmatic eruptions were triggered by a very efficient magma and water interaction. This is in comparison to WPB or AVF phreatomagmatic volcanoes, where magma intruded fine sand to gravelly, water rich, soft-substrate, that was "easy" to fragment to its mineral component level, preventing the preservation of any large muddy chunks intruded by magma.

\section{Discussion}

It is commonly reported that the shape and geometry of small volcanoes strongly depends on the "rock or substrate" environment through which the volcano erupts [69, 71]. In general, in soft rock sediment environments, tuff rings and maars tend to develop broad, flat, and shallow craters. By contrast, in "hard" rock environments the crater walls stay stable, and the root zone may reach greater depths $[69,71]$. To distinguish volcanic landforms associated with specific host rock environments, it is important to properly identify eroded volcanic fields. Quite often only the diatreme is preserved in eroded volcanic fields. Pyroclastic deposits and rocks preserved in the diatremes will reflect the excavation depth of country rocks, the level of fragmentation/explosion and the total contribution of the country rocks to the formation of the volcano. In the case of shallow depth explosion and fragmentation, the pyroclastic rocks are usually juvenile fragment-dominated and mixed with small volumes of unconsolidated ("soft") rocks that may be incorporated into the volcanic debris. When the explosion takes place in a "soft" substrate at deeper levels, the erupted tephra enclose rock and mineral fragments from the unconsolidated "soft" substrate. By contrast, the erupted tephra will contain rock fragments in the case of deep level explosions occurring in coherent ("hard") rock units. Estimates of the total proportion of accidental lithics and their lithological characteristics could be a solid base to reconstruct the geometrical parameters of the original volcanic landform [103]. This is because in eroded maars the only preserved part of the volcano is the diatreme. The determination of its rock type can therefore help to establish the characteristics of the original volcanic landform. The reconstruction of a volcano that erupted in "soft" rock environment generally shows a broad shape with a shallow crater (Figure 14A). By using this method, the estimation of the initial position of the syn-eruptive landscape would suggest less erosion than is deduced by considering only the preserved diatreme geometry. When there is evidence to support the "hard" rock hypothesis, the size of the preserved diatreme may indicate a deeper position in the syn-volcanic succession (Figure 14B). Thus, any estimate of syn-volcanic landscape position would be higher than is suggested by the diatreme geometry. In the western Pannonian Basin, diatremes in the Little Hungarian Plain Volcanic Field represent volcanoes that erupted through "soft" substrate. Therefore, their current position represents a shallow depth below the syn-volcanic landscape. By contrast, in the Bakony - Balaton Highland Volcanic Field, eruptions occurred through "hard" rock units. Thus the preserved diatremes contain mainly volcanic conduit filling rocks that are found at deeper levels below the synvolcanic landscape, than can be estimated from the simple geometrical dimensions of the diatreme itself.

Field observations and theoretical considerations demonstrated well in the past two decades, that phreatomagmatic monogenetic volcanism, is strongly controlled by external parameters such as the availability of ground and/or surface water, the nature of water storage in var- 


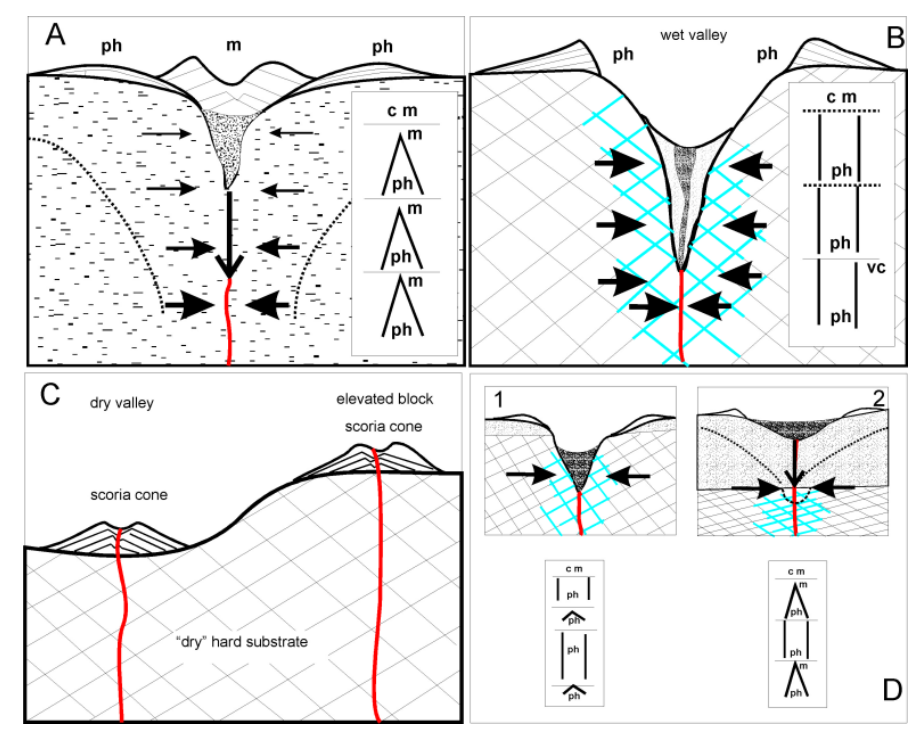

Figure 14. Eruptive scenario of monogenetic volcanism when rising magma interacts with ground water stored in soft substrate. The magma "uses" the available ground water, that cannot be immediately recharged, and therefore a cone of depression forms, driving the explosion locus deeper and deeper. As a result the eruptive sequence will be a sequence gradually changing from pyroclastic rock beds indicating pure phreatomagmatic explosive interactions $(\mathrm{ph})$ to a magmatic fragmentation dominated eruption sequence $(\mathrm{m})$. In the end of the eruption, magmatic capping units $(\mathrm{c} \mathrm{m}$ ) will form, with common formation of a scoria cone and lava lake complex in the crater. If there are repeated sets of pyroclastic beds representing "wet - to - dry" cycles, usually separated by explosion breccias (horizontal line in inset) a polycyclic, and potentially polymagmatic eruption can be suspected.

Eruptive scenario of monogenetic volcanism when rising magma interacts with ground water stored in hard-substrate. Ground water stored in fractures that are hydrologically more active along valley floors. Water can be recharged immediately during the phreatomagmatic magma water interaction, and therefore phreatomagmatic eruption can be sustained over the entire course of the eruption resutling in a pure phreatomagmatic succession. Tuff breccia horizons in such scenarios equally could be linked to conduit wall collapses (continuous line - marked as "vc") as well as to new eruptive cycles (dotted lines). Magmatic infill and or capping units $(\mathrm{c} \mathrm{m}$ ) can develop if the eruption by some reason disrupts the water recharge system. In such cases the water would then be cut off immediately that results a very abrupt facies change in the pyroclastic sequence.

In dry climatic conditions even valley floors would not have been active and could give way to form scoria cones. In hard-substrate environment, presence of scoria cones along valley floors means some dramatic event triggered by climatic conditions. In elevated areas, scoria cones are also prone to form over phreatomagmatic volcanoes due to lack of water in elevated areas.

In mixed substrate type, two major types can be separated 1) thin soft substrate cover over hard-substrate and 2) thick soft substrate cover over hard substrate. In the first case the soft substrate influence would be limited, and potentially would be restricted to a short lived event providing accumulation of thin tephra rich plastically deformed clasts from the soft substrate. Repeated eruptions would provide potentially thicker tuff breccia horizons separating units representing separate different cycles. In the second case, the soft substrate influence would be more dominant, and the accumulating pyroclastic succession expected to be very complex, where conduit and crater dynamics, recycling, and abrupt and quick changes in eruption styles would be common.

ious aquifers, and how the aquifer is structurally altered $[104,105]$. In hard substrate environments the ground water is stored in joints and fractures that are naturally more common in areas where old and/or recent and still active fractures exist (Figure 14B). Such fracture zones are hydrologically more active in valley floors and heads of valleys, where surface water input can provide additional supply to the ground water flow (Figure 14B). From the West Eifel out of 69 maars, 67 erupted in valley floors of the fracture controlled aquifer dominated country rocks [69]. Because fractured aquifers are typically fast in water-recharge, it is inferred that water may potentially be available throughout an eruption if magma encounters hydrologically active zones. As a result, nearcontinuous, thick phreatomagmatic successions with few inter-beds of pyroclastic units indicating magmatic frag- mentation dominated explosive eruptions will form (Figure 14B). Unconformities and/or characteristic explosive breccia horizons in these pyroclastic successions likely represent volcanic conduit wall collapse events that may have been triggered by newly emplaced magma and therefore would indicate polycyclic or even polymagmatic eruptions (Figure 14B). So, thick phreatomagmatic successions with abundant hard (and therefore intact) country rock fragments, with characteristic explosion breccia horizons are likely candidates for polycyclic monogenetic eruptions, and could also indicate polymagmatic activity. Over fracture controlled aquifers away from the hydrologically active zones, the rising magma will fragment magmatically and form scoria cones, lava fissures and emit lava flows (Figure 14C). In this case monogenetic volcanic fields over hard substrate will likely be very diverse, and character- 
istically different from eruption points to eruption points following the trend of the hydrologic activity of the country rocks. Magmatic infill on phreatomagmatic volcanoes is expected to be rare. The distribution of phreatomagmatic and magmatic volcano types will be rather dispersed, and transition in the eruptive sequence is not expected.

In soft rock environments the rising magma will intrude into shallow levels, where it will interact with pore water triggering thermohydraulic explosions (Figure 14A). Due to the slow recharge rate of the porous media aquifers the initial explosions immediately create a cone of depression in the ground-water, forcing the eruption locus to down-migrate (Figure 14A). As a consequence the down-migration will sample country rocks from deeper and deeper regions and this will appear higher and higher in the accumulating tephra ring sequences. The process will continue until the explosion locus will reach such depth below surface, that the explosion cannot provide enough energy to clear the conduit. As a consequence the intruding magma will gradually exhaust the ground water source, drying it out by its heat, and the porous media aquifer will not able to recharge to sustain phreatomagmatic explosive eruptions. As a result, the eruption will gradually shift to be dominated more by magmatic fragmentationand if the magma supply is large enough, produce a lava outpour (Figure 14A). The resulting pyroclastic succession will show a gradual "drying out" event by an increased number of magmatically fragmented pyroclastdominated beds higher in the accumulating tephra ring section (Figure 14A). In such a scenario, well-defined explosion breccia horizons, rich in plastically deformed mud, silt and sand from the soft substrate in the preserved pyroclastic succession indicates a) potential magma flux drop that gives time to recharge the soft substrate with water, triggering renewed vent-clearing phreatomagmatic events and/or b) a resumed eruptive episode that may be separated by hours to days from the previous ones (Figure 14A). Due to the hours to days time scale an exhausted typical porous media aquifer needs to be recharged, it is likely that the presence of such explosion horizons in the case of soft substrate controlled phreatomagmatic eruptions are evidence of polycyclic monogenetic activity (Figure 14A).

The complications are evident, when the country rock stratigraphy is a combined aquifer (Figure 14D) such as certain parts of the BBHVF (Figure 2). The most typical scenario is a hard rock basement covered by thin veneers of basin filling siliciclastic deposits. In this situation, the eruption mechanism of the newly formed monogenetic volcano will be controlled by the combination of both aquifers, and the relative role of each will largely depend on the thickness of the soft substrate (Figure 14D).
The WPB volcanoes show evidence of soft substrate control in the Little Hungarian Plain Volcanic Field ( $\mathrm{LH}-$ PVF) and in the areas where thick soft substrate covers basement-forming hard rocks at the BBHVF. The eruptive sequences of the LHPVF however demonstrate rather simple successions, indicating typical monogenetic phreatomagmatic eruption dominated scenarios, similar to most of the AVF and PAVF sections. In the BBHVF, however, the deeper hard substrate influence is evident by the presence of a large volume of country rocks in the pyroclastic rock units from deep sources.Additionally, in these areas phreatomagmatic volcanoes seem to form volcanic complexes with complex pyroclastic successions with characteristic explosion breccia horizons, suggesting longevity and potential complex magmatic plumbing system of these volcanoes. This scenario is very similar to those known from the Jeju Island such as Songaksan tuff ring, which represent a volcano that erupted through a combined aquifer.

\section{Conclusion}

Monogenetic volcanoes of the volcanic fields of the WPB are strongly eroded, their original landform modified in various levels, and today, only the proximal pyroclastic successions and capping magmatic infill is preserved making it hard to reconstruct the original volcanic landform. The high ratio of accidental lithic fragments from the immediate underlying pre-volcanic "soft substrate" in most of the WPB volcanoes indicate that phreatomagmatic explosive events were controlled by the hydrological conditions of these uppermost rock units. In this respect the WPB volcanoes are very similar to broad and shallow maars and associated tuff rings located in Auckland, and also share similarities with many of the phreatomagmatic volcanoes of Pali Aike. Jeju however contains volcanoes that are formed by surface and near surface water and magma explosive interaction, resulting in an overwhelming proportion of juvenile pyroclasts in their successions, similar to the volcanoes located in the Little Hungarian Plain Volcanic Field. This relationship indicates that at the WPB the NW-side of the volcanic fields are more characteristic to volcanoes formed due to the strong influence of surface and soft-substrate sub-surface aquifers. In the central part of the WPB volcanic fields the influence of the soft substrate is apparent, and formed similar volcanoes to the majority of the Auckland phreatomagmatic volcanoes. In the eastern part of the Bakony-Balaton Highland Volcanic Field, the thin veneer of soft-substrate covering hard-substrate gave rise to the potential of phreatomagmatic volcanoes controlled by deep water sources and re- 
sulted in volcanic complexes similar to large tuff rings on Jeju Island (Suwolbong).

In this comparative study we provided some links to modern volcanic landforms that need to be envisaged in the reconstruction of volcanic landforms and associated synvolcanic landscapes where volcanic fields formed in the western Pannonian Basin. In this respect, Auckland, Pali Aike, and Jeju Islands are potentially the best locations to find modern analogies to most of the volcanic remnants of the western Pannonian Basin.

\section{Acknowledgements}

The results presented here are part of research projects supported by the Foundation for Research, Science and Technology International Investment Opportunities Fund Project MAUX0808 to SJC "Facing the challenge of Auckland volcanism", Massey University Research Fund (RM13227) to KN, OTKA - Hungarian Science Foundation to GCs, the Hungarian - Argentine Bilateral Science and Technology Cooperation project AR02/3 to KN and MJH and the ISAT Argentine - New Zealand Science and Technology cooperation project to KN. The Massey University Leave \& Ancillary Appointments Committee granted fund (LAAC10/37) allowed KN to attend on the XIX Congress of the Carpathian Balkan Geological Association in Thessaloniki in 23-26 September 2010 where this work was presented. Suggestions by Journal reviewers, Managing Editor, Katarzyna Cyran and Technical Editor, Michat Ciemata greatly improved the science and presentation style of this work.

\section{References}

[1] White J.D.L., Maar-diatreme phreatomagmatism at Hopi Buttes, Navajo Nation (Arizona), USA, B. Volcanol., 1991, 53, 239-258

[2] Manville V., Nemeth K., Kano K., Source to sink: A review of three decades of progress in the understanding of volcaniclastic processes, deposits, and hazards, Sediment. Geol., 2009, 220, 136-161

[3] Lorenz V., On the growth of maars and diatremes and its relevance to the formation of tuff rings, $B$. Volcanol., 1986, 48, 265-274

[4] Lorenz V., Maars and diatremes of phreatomagmatic origin: a review, Transactions of the Geological Society of South Africa, 1985, 88, 459-470

[5] Lorenz V., Kurszlaukis S., Root zone processes in the phreatomagmatic pipe emplacement model and consequences for the evolution of maar-diatreme vol- canoes, J. Volcanol. Geoth. Res., 2007, 159, 4-32

[6] Martin U., Németh K., Mio/Pliocene phreatomagmatic volcanism in the western Pannonian Basin, Geologica Hungarica Series Geologica, 2004, Budapest, Geological Institute of Hungary

[7] Allen S.R., Bryner V.F., Smith I.E.M., Ballance P.F., Facies analysis of pyroclastic deposits within basaltic tuff-rings of the Auckland volcanic field, New Zealand, New Zeal. J. Geol. Geop., 1996, 39, 309-327

[8] Magill, C., Blong, R., Volcanic risk ranking for Auckland, New Zealand. I: Methodology and hazard investigation, B. Volcanol., 2005, 67, 331-339.

[9] Houghton B.F., Wilson C.J.N., Rosenberg M.D., Smith I.E.M., Parker R.J., Mixed deposits of complex magmatic and phreatomagmatic volcanism: An example from Crater Hill, Auckland, New Zeal. B. Volcanol., 1996, 58, 59-66

[10] von Veh M.W., Nemeth K., An assessment of the alignments of vents on geostatistical analysis in the Auckland Volcanic Field, New Zealand. Geomorphologie-Relief Processus Environnement, 2009, 175-186

[11] Németh K., Martin U., Late Miocene paleogeomorphology of the Bakony-Balaton Highland Volcanic Field (Hungary) using physical volcanology data, Z. für Geomorph., 1999, 43, 417-438

[12] Németh K., Martin U., Philippe M., Eroded porousmedia aquifer controlled hydrovolcanic centers in the South Lake Balaton region, Hungary; the Boglár Volcano, Acta Geologica Hungarica, 1999, 42, 251266

[13] Németh K., Martin U., Csillag G., Erosion rate calculation based on eroded monogenetic alkaline basaltic volcanoes of the Mio/Pliocene BakonyBalaton Highland Volcanic Field, Hungary, Geolines, 2003, 15, 93-97

[14] Németh K., Martin U., Large hydrovolcanic field in the Pannonian Basin: general characteristics of the Bakony - Balaton Highland Volcanic Field, Hungary, Acta Vulcanologica, 1999, 11, 271-282

[15] Ruszkiczay-Rüdiger Z., Fodor L., Horváth E., Telbisz T., Discrimination of fluvial, eolian and neotectonic features in a low hilly landscape: A DEM-based morphotectonic analysis in the Central Pannonian Basin, Hungary, Geomorphology, 2009, 104, 203217

[16] Sohn Y.K., Hydrovolcanic processes forming basaltic tuff rings and cones on Cheju Island, Korea, Geol. Soc. Am. Bull., 1996, 108, 1199-1211.

[17] Sohn Y.K., Park K.H., Yoon S.H., Primary versus secondary and subaerial versus submarine hydro- 
volcanic deposits in the subsurface of Jeju Island, Korea, Sedimentology, 2008, 55, 899-924

[18] Sohn Y.K., Park K.H., Early-stage volcanism and sedimentation of Jeju island revealed by the Sagye Borehole, SW Jeju Island, Korea. Geosci. J., 2004, 8, 73-84

[19] Sohn Y.K., Chough S.K., Depositional processes of the Suwolbong Tuff Ring, Cheju Island (Korea). Sedimentology, 1989, 36, 837-855

[20] Briggs R.M., Okada T., Itaya T., Shibuya H., Smith I.E.M., K-Ar Ages, paleomagnetism, and geochemistry of the South Auckland Volcanic Field, NorthIsland, New-Zealand, New Zeal. J. Geol. Geop., 1994, 37, 143-153

[21] Spörli K.B., Eastwood, V.R., Elliptical boundary of an intraplate volcanic field, Auckland, New Zealand. J. Volcanol. Geoth. Res., 1997, 79, 169-179

[22] Kermode L.O., Geology of the Auckland urban area (with map in scale 1: 50 000). Institute of Geological \& Nuclear Sciences geological map 2. 1 sheet + Explanatory Book, 1992, Institute of Geological \& Nuclear Sciences, Lower Hutt, New Zealand

[23] Rogan W., Blake S., Smith I., In situ chemical fractionation in thin basaltic lava flows: Examples from the Auckland volcanic field, New Zealand, and a general physical model, J. Volcanol. Geoth. Res., 1996, 74, 89-99

[24] Affleck D.K., Cassidy J., Locke C.A., Te Pouhawaiki Volcano and pre-volcanic topography in central Auckland: volcanological and hydrogeological implications, New Zealand Journal of Geology and Geophysics, 2001, 44, 313-321

[25] Cassidy J., France S.J., Locke C.A., Gravity and magnetic investigation of maar volcanoes, Auckland volcanic field, New Zealand. Journal of Volcanology and Geothermal Research, 2007, 159, 153-163

[26] Marra M.J., Alloway B.V., Newnham R.M., Paleoenvironmental reconstruction of a well-preserved Stage 7 forest sequence catastrophically buried by basaltic eruptive deposits, northern New Zealand, Quaternary Science Reviews, 2006, 25, 2143-2161

[27] Martin U., Németh K., Eruptive and depositional history of a Pliocene tuff ring that developed in a fluviolacustrine basin: Kissomlyó Volcano (Western Hungary), J. Volcanol. Geoth. Res., 2005, 147, 342356

[28] Heiken G.H., Tuff Rings - Examples From Fort RockChristmas Lake Valley Basin, South Central Oregon, J. Geophys. Res., 1971, 76, 5615

[29] Houghton B.F., Wilson C.J.N., Smith I.E.M., Shallow-seated controls on styles of explosive basaltic volcanism: a case study from New Zealand,
J. Volcanol. Geoth. Res., 1999, 91, 97-120

[30] Auer A., Martin U., Németh K., The Fekete-hegy (Balaton Highland Hungary) "soft-substrate" and "hard-substrate" maar volcanoes in an aligned volcanic complex - Implications for vent geometry, subsurface stratigraphy and the palaeoenvironmental setting, J. Volcanol. Geoth. Res., 2007, 159, 225-245

[31] Cronin S.J., Németh K., Smith I.E.M., Leonard G., Shane P., Possible rejuvenation of volcanism at the "monogenetic" phreatomagmatic/magmatic volcanic complex of Panmure Basin, Auckland Volcanic Field, New Zealand. In: Haller M.J. and Massaferro G. (Eds.), IAVCEI-IAS 3rd International Maar Conference 2009. Malargue, Argentina: Asociacion Geologica Argentina

[32] Németh K., Cronin S.J., Smith I.E.M., Stewart R.B. Mechanisms of a maar-forming eruption through soft fine-grained sedimentary substrate: Orakei Basin, Auckland, New Zealand. In: Haller M.J. and Massaferro G. (Eds.), IAVCEI-IAS 3rd International Maar Conference 2009. Malargue, Argentina: Asociacion Geologica Argentina

[33] McDougall I., Pollack H.A., Stipp J.J., Excess radiogenic argon in young subareal basalts from Auckland volcanic field, New Zealand. Geochim. Cosmochim. Acta, 1969, 33, 1485-1520

[34] Allen S.R., Bryner V.F., Smith I.E.M., Ballance P.F., Auckland volcanic field tuff ring deposits. In: Anonymous Editor, International volcanological congress, IAVCEI; abstracts., 1994, IAVCEI

[35] Allen S.R., Smith I.E.M., Eruption styles and volcanic hazard in the Auckland volcanic field, New Zealand. Geosci. Rep. Shizuoka Univ., 1994, 20, 514

[36] Corbella H., El campo volcano-tectónico de Pali Aike, In: Haller M. ed,. Geología y Recursos Naturales de Santa Cruz, Asociación Geológica Argentina, 2002, Buenos Aires, 285-302

[37] Mazzarini F., D'Orazio M., Spatial distribution of cones and satellite-detected lineaments in the Pali Aike Volcanic Field (southernmost Patagonia): insights into the tectonic setting of a Neogene rift system, J. Volcanol. Geoth. Res., 2003, 125, 291-305

[38] Bruni S., D'Orazio M., Haller M.J., Innocenti F., Manetti P., Pecskay Z., Tonarini S., Time-evolution of magma sources in a continental back-arc setting: the Cenozoic basalts from Sierra de San Bernardo (Patagonia, Chubut, Argentina), Geol. Mag., 2008, 145, 714-732

[39] Massaferro G.I., Haller M.J., D'Orazio M., Alric V.I., Sub-recent volcanism in Northern Patagonia: A tectonomagmatic approach, J. Volcanol. Geoth. Res., 
2006, 155, 227-243

[40] D'Orazio M., Innocenti F., Manetti P., Haller M.J., Di Vincenzo G., Tonarini S., The Late Pliocene mafic lavas from the Camusu Aike volcanic field (similar to 50 degrees S, Argentina): Evidence for geochemical variability in slab window magmatism, J. S. Am. Earth Sci., 2005, 18, 107-124

[41] D'Orazio M., Innocenti F., Manetti P., Tamponi M., Tonarini S., Gonzalez-Ferran O., Lahsen A., Omarini R., The Quaternary calc-alkaline volcanism of the Patagonian Andes close to the Chile triple junction: geochemistry and petrogenesis of volcanic rocks from the Cay and Maca volcanoes (similar to 45 degrees S, Chile), J. S. Am. Earth Sci., 2003, 16, 219-242

[42] D'Orazio M., Agostini S., Innocenti F., Haller M.J., Manetti P., Mazzarini F., Slab window-related magmatism from southernmost South America: the Late Miocene mafic volcanics from the Estancia Glencross area (similar to 52 degrees $\mathrm{S}$, Argentina-Chile), Lithos, 2001, 57, 67-89

[43] D'Orazio M., Agostini S., Mazzarini F., Innocenti F., Manetti P., Haller M.J., Lahsen A., The Palil Aike Volcanic Field, Patagonia: slab-window magmatism near the tip of South America. Tectonophysics, 2000, 321, 407-427

[44] De Ignacio C., Lopez I., Oyarzun R., Marquez A., The northern Patagonia Somuncura plateau basalts: a product of slab-induced, shallow asthenospheric upwelling? Terra Nova, 2001, 13, 117-121

[45] Haller M.J., Németh K., Architecture and pyroclastic succession of a small Quaternary (?) maar in the Pali Aike Volkanic Field, Santa Cruz, Argentina, Zeitschrift der deutschen geologischen Gesellschaft, 2006, 157, 467-476

[46] Ross P.S., Delpit S., Haller M.J., Németh K., Corbella $\mathrm{H}$., Influence of the substrate on maar-diatreme volcanoes - an example of a mixed setting from the Pali Aike volcanic field, Argentina, J. Volcanol. Geoth. Res., 2010, (in press)

[47] Fejfar O., Heinrich W.D., Importance of two sites of fossil vertebrates, Ivanovce and Hajnacka, for mammalian paleontology in European Pliocene and Early Pleistocene: present stage of knowledge and problems,Vestnik Ustredniho Ustavu Geologického, 1985, 60, 213-224

[48] Hably L., Kvacek Z., Pliocene mesophytic forests surrounding crater lakes in western Hungary. Revi. Palaeobot. Palyn., 1998, 101, 257-269

[49] Kvacek Z., Hably L., Szakmány G., Additions to the Pliocene flora of Gérce (Western Hungary). Földtani Közlöny (Bulletin of the Hungarian Geological Society), Budapest, 1994, 124, 69-87
[50] Fischer O., Hably L., Pliocene flora from the alginite at Gérce. Ann. Hist.-Nat. Mus. Natl. Hungary, 1991, 83, 25-47

[51] Kordos L., Hajós M., Müller P., Nagy E., Environmental change and ecostratigraphy in the Carpathian Basin, Annales Instituti Geologici Publici Hungarici, 1987, 70, 377-391

[52] Kereszturi G., Németh K., Csillag G., Kovács, J., Balogh, K., The role of external environmental factors in changing eruption styles of monogenetic volcanoes in a Pliocene continental volcanic field in western Hungary. J. Volcanol. Geoth. Res., 2010, (in press)

[53] Mayr C., Lucke A., Maidana N.I., Wille M., Haberzettl T., Corbella H., Ohlendorf C., Schabitz $\mathrm{F}$., et al, Isotopic fingerprints on lacustrine organic matter from Laguna Potrok Aike (southern Patagonia, Argentina) reflect environmental changes during the last 16,000 years. J. Paleolimnol., 2009, 42, 81102

[54] Anselmetti F.S., Ariztegui D., De Batist M., Gebhardt A.C., Haberzettl T., Niessen F., Ohlendorf C., Zolitschka B., Environmental history of southern Patagonia unravelled by the seismic stratigraphy of Laguna Potrok Aike, Sedimentology, 2009, 56, 873892

[55] Haberzettl T., Kuck B., Wulf S., Anselmetti F., Ariztegui D., Corbella H., Fey M., Janssen S., et al., Hydrological variability in southeastern Patagonia and explosive volcanic activity in the southern Andean Cordillera during Oxygen Isotope Stage 3 and the Holocene inferred from lake sediments of Laguna Potrok Aike, Argentina. Palaeo. Palaeo. Palaeo., 2008, 259, 213-229

[56] Chen Y., Zhang Y.X., Graham D., Su S.G., Deng J.F., Geochemistry of Cenozoic basalts and mantle xenoliths in Northeast China, Lithos, 2007, 96, 108-126

[57] Sohn Y.K., Park K.H., Phreatomagmatic volcanoes of Jeju Island, Korea. IAVCEI-CEV-CVS Field Workshop, Jeju Island, Korea, November 13-17, 2007. Jeju Special Self-Governing Province, Jeju, Korea, 2007

[58] Hamdy A.M., Park P.H., Lim H.C., Park K.D., Present-day relative displacements between the Jeju Island and the Korean peninsula as seen from GPS observations, Earth Planets Space, 2004, 56, 927931

[59] Hamdy A.M., Park P.H., Jo B.G., Preliminary crustal movement study around the Honam shear zone and Okchon Belt (South Korea) using GPS observations, Geosci. J., 2004, 8, 109-112

[60] Jin S.G., Park P.H., Zhu W.Y., Micro-plate tectonics and kinematics in Northeast Asia inferred from a 
dense set of GPS observations. Earth Planet. Sci. Lett., 2007, 257, 486-496

[61] Koh J.S., Yun S.H., Kang S.S., Petrology of the volcanic rocks in the Paekrogdam Crater area, Mt. Halla, Jeju Island, Journal of the Petrological Society of Korea, 2003, 12, 1-15

[62] Kang S., Benthic foraminiferal biostratigraphy and paleoenvironments of the Seogwipo Formation, Jeju Island, Korea, Journal of the Paleontological Society of Korea, 2003, 19, 63-153

[63] Németh K., Martin U., Harangi S., Miocene phreatomagmatic volcanism at Tihany (Pannonian Basin, Hungary), J. Volcanol. Geoth. Res., 2001, 111, 111-135

[64] Won J.H., Lee J.Y., Kim J.W., Koh G.W., Groundwater occurrence on Jeju Island, Korea, Hydrogeol. J., 2006, 14, 532-547

[65] Tatsumi Y., Shukuno H., Yoshikawa M., Chang Q., Sato K., Lee M.W., The petrology and geochemistry of volcanic rocks on Jeju Island: plume magmatism along the Asian continental margin. J. Petrol., 2005, 46, 523-553

[66] Sohn Y.K., Park K.H., Composite tuff ring/cone complexes in Jeju Island, Korea: possible consequences of substrate collapse and vent migration, J. Volcanol. Geoth. Res., 2005, 141, 157-175

[67] Wijbrans J., Németh K., Martin U., Balogh K., Ar40/Ar-39 geochronology of Neogene phreatomagmatic volcanism in the western Pannonian Basin, Hungary, J. Volcanol. Geoth. Res., 2007, 164, 193204

[68] White J.D.L., McClintock M.K., Immense vent complex marks flood-basalt eruption in a wet, failed rift: Coombs Hills, Antarctica, Geology, 2001, 29, 935938

[69] Lorenz V., Maar-diatreme volcanoes, their formation, and their setting in hard-rock or soft-rock environments. Geolines, 2003, 15, 72-83

[70] Lorenz, V., Suhr, P., Goth, K., Maar-DiatremVulkanismus â€Ș Ursachen und Folgen. Die Guttauer Vulkangruppe in Ostsachsen als Beispiel für die komplexen Zusammenhänge (Maar-diatreme volcanism â€Ș causes and consequences. The Guttau Volcano Group ineastern Saxony as an example for the complex processes and relationships), Zeitschriftfür Geologische Wissenschaften (Journal for the Geological Sciences) - ISSN 0303-4534., Berlin, 2003, 31, 267-312

[71] Lorenz V., Syn- and post-eruptive processes of maardiatreme volcanoes and their relevance to the accumulation of post-eruptive maar crater sediments, Földtani Kutatás (Quaterly Journals of the Geolog- ical Survey of Hungary), Budapest, 2003, 40, 13-22.

[72] Skilling I.P., White J.D.L., McPhie J., Peperite: a review of magma-sediment mingling. J. Volcanol. Geoth. Res., 2002, 114, 1-17

[73] Martin U., Németh K., Blocky versus fluidal peperite textures developed in volcanic conduits, vents and crater lakes of phreatomagmatic volcanoes in Mio/Pliocene volcanic fields of Western Hungary, J. Volcanol. Geoth. Res., 2007, 159, 164-178

[74] Busby-Spera C.J., White J.D.L., Variation in peperite textures associated with differing host-sediment properties, Bull. Volcanol., 1987, 49, 765-775

[75] Balogh K., Németh K., Evidence for the neogene small-volume intracontinental volcanism in western Hungary: K/Ar geochronology of the Tihany Maar volcanic complex, Geol. Carpath., 2005, 56, 91-99

[76] Balogh K., Árva-Sós E., Pécskay Z., RavaszBaranyai L., K/Ar dating of post-Sarmatian alkali basaltic rocks in Hungary, Acta Mineralogica et Petrographica, Szeged, 1986, 28, 75-94

[77] Balogh K., Pécskay Z., K/Ar and Ar/Ar geochronological studies in the Pannonian-CarpathiansDinarides (PANCARDI) region, Acta Geologica Academiae Scientiarum Hungaricae, 2001, 44, 281301

[78] Budai T., Csillag G., A Balaton-felvidék földtana: magyarázó a Balaton-felvidék földtani térképéhez, 1:50 000 (Geology of the Balaton Highland: explanatory booklet for the geology map of the Balaton Highland, scale 1:50 000), In: Brezsnyánszky K. (Ed.), Occasional Papers of the Geological Institute of Hungary, 197, Geological Institute of Hungary, Budapest, 1999

[79] Németh K., Martin U., Magyar I., Field guide to Pliocene phreatomagmatic volcanoes along the Raba Fault Zone, Western Hungary. International Union of Geological Sciences - Subcommission on Neogene Stratigraphy: Regional Committee on Mediterranean Neogene Stratigraphy - "Patterns and Processes in the Neogene of the Mediterranean Region ", 2005

[80] Magyar I., Geary D.H., Muller P., Paleogeographic evolution of the Late Miocene Lake Pannon in Central Europe. Palaeogeogr. Palaeocl., 1999, 147, 151167

[81] Sacchi M., Horváth F., Magyar I., Müller P., Problems and progress in establishing a Late Neogene Chronostratigraphy for the Central Paratethys, Neogene Newsletter, Padova, 1997, 4, 37-46

[82] Sacchi M., Horváth F., Magyari O., Role of unconformity-bounded units in the stratigraphy of the continental cord; a case study from thelate 
Miocene of the western Pannonian Basin, Hungary, In: Durand B., Jolivet L., Horváth F., Ranne M., (eds.), The Mediterranean basins; Tertiary extension within the Alpine Orogen., 1999, Geological Society of London, London, 357-390

[83] Sacchi M., Horváth F., Towards a new time scale for the Upper Miocene continental series of the Pannonian basin (Central Paratethys). In: Cloetingh S.A.P.L., Horváth F., Bada G., and Lankreijer A.C. (Eds.), Neotectonics and surface processes: the Pannonian Basin and Alpine/Carpathian System, Stephan Mueller Special Publication Series, 2002, 79-94

[84] Kereszturi G., Csillag G., Németh K., Sebe K., Balogh K., Jáger V., Volcanic architecture, eruption mechanism and landform evolution of a Pliocene intracontinental basaltic polycyclic monogenetic volcano from the Bakony- Balaton Highland Volcanic Field, Hungary, Cent. Eur. J. Geosc., 2010, (in press)

[85] Fisher R.V., Schmincke H.U., Pyroclastic Rocks, 1984, Springer, Heidelberg

[86] Valentine G.A., Gregg T.K.P., Continental basaltic volcanoes - Processes and problems, J. Volcanol. Geoth. Res., 2008, 177, 857-873

[87] Lorenz V., McBirney A.R., Williams H., An investigation of volcanic depressions. Part III. Maars, tuffrings, tuff-cones and diatremes, NASA Progress Report (NGR - 38-003,012). 1970, Houston, Texas: Clearinghouse for Federal Scientific and Technical Information, Springfield

[88] Waters A.C., Fisher R.V., Maar volcanoes, In: Gilmour E.H. and Stradling D. (Eds.), Proceedings of the 2nd Columbia River Basalt Symposium, 1970, Eastern Washington State College Press: Cheney Washington,157-170

[89] Keating G.N., Valentine G.A., Krier D.J., Perry F.V., Shallow plumbing systems for small-volume basaltic volcanoes, Bull. Volcanol., 2008, DOI 10.1007/s00445-007-0154-1

[90] Kienle J., Kyle P.R., Self S., Motyka R.J., Lorenz V., Uninrek Maars, Alaska, 1. April 1977 eruption sequence, petrology, and tectonic settings, J. Geophys. Res., 1980, 7, 11-37

[91] Self S., Kienle J., Huot J.P., Ukinrek Maars, Alaska 2. Deposits and formation of the 1977 craters, J. Volcanol. Geoth. Res., 1980, 7, 39-65

[92] Müller G., Veyl G., The birth of Nilahue, a new maar type volcano at Rininahue, Chile. In: GarcÃ $\infty$ a Rojas A. (Ed.), Congreso Geologico Internacional, 1956, Seccio I - Vulcanologia del Cenozoico Mexico D.F., 375-396

[93] Wohletz K.H., Mechanisms of hydrovolcanic pyro- clast formation: grain-size, scanning electron microscopy, and experimental studies, J. Volcanol. Geoth. Res., 1983, 17, 31-63

[94] Sheridan M.F., Wohletz K.H., Hydrovolcanism - Basic considerations and review, J. Volcanol. Geoth. Res., 1983, 17, 1-29

[95] Wohletz K.H., McQueen R.G., Experimental studies in hydromagmatic volcanism in Studies in Geophysics: Explosive volcanism: Inception, evolution and hazards. 1984, National Academy Press, Washington

[96] Wohletz K.H., Explosive magma-water interactions: Thermodynamics, explosion mechanisms, and field studies. Bull. Volcanol., 1986, 48, 245-264

[97] Wohletz K., Heiken G., Volcanology and geothermal energy, 1992, University of California Press, Berkeley

[98] Keating G.N., Valentine G.A., Krier D.J., Perry F.V., Shallow plumbing systems for small-volume basaltic volcanoes, Bull. Volcanol., 2008, 70, 563-582

[99] Funiciello R., Giordano G., De Rita D., The Albano maar lake (Colli Albani Volcano, Italy): recent volcanic activity and evidence of pre-Roman Age catastrophic lahar events, J. Volcanol. Geoth. Res., 2003, 123, 43-61

[100] Valentine G.A., Krier D.J., Perry F.V., Heiken G., Eruptive and geomorphic processes at the Lathrop Wells scoria cone volcano., J. Volcanol. Geoth. Res. 2007, 161, 57-80

[101] Balogh K., Jámbor A., Partényi Z., Ravaszné Baranyai L., Solti G., A dunántúli bazaltok K/Ar radiometrikus kora (K/Ar radigenic age of Transdanubian basalts), (in Hungarian with English summary), MÁFI Évi Jelentése 1980-ról (Annual Report of the Geological Institute of Hungary), 1982, 243-259

[102] Brenna M., Cronin S.J., Smith I.E.M., Sohn Y.-K., Németh K., Mechanisms driving polymagmatic activity at a monogenetic volcano, Udo, Jeju Island, South Korea, Contrib. Mineral. Petr., 2010, DOI 10.1007/s00410-010-0515-1

[103] Németh K., Martin U., Csillag G., Calculation of erosion rates based on remnants of monogenetic alkaline basaltic volcanoes in the Bakony-Balaton Highland Volcanic Field (Western Hungary) of Mio/Pliocene age, Geolines, 2003, 15, 93-97

[104] Lorenz V., On the formation of Maars, Bull. Volcanol., 1973, 37, 183-204

[105] Lorenz V., Phreatomagmatism and its relevance. Chem. Geol., 1987, 62, 149-156 